Part of Journal of Research of the National Bureau of Standards, Volume 34, May 1945

\title{
METHOD FOR CALCULATING THE PROPERTIES OF HYDROCARBONS AND ITS APPLICATION TO THE REFRACTIVE INDICES, DENSITIES, AND BOILING POINTS OF THE PARAFFIN AND MONOOLEFIN HYDRO. CARBONS $^{1}$
}

\author{
By William J. Taylor, ${ }^{2}$ Joan M. Pignocco, ${ }^{2}$ and Frederick D. Rossini
}

ABSTRACT

A method is described for calculating the properties of hydrocarbons which involves the summation of contributions from component parts of the molecule, together with contributions from interactions between adjacent component parts.

For the paraffin hydrocarbons, the calculations were made in terms of the difference in the value of the property between a given normal paraffin and its isomers, and the required constants were evaluated from data on 33 paraffins, $\mathrm{C}_{5}$ to $\mathrm{C}_{8}$. For these paraffins, the average deviation of the calculated from the experimental values is $\pm 0.00074 \mathrm{~g} / \mathrm{ml}$ in density, \pm 0.00042 in refractive index $\left(n_{D}\right.$ at $\left.20^{\circ} \mathrm{C}\right)$, and $\pm 0.55^{\circ} \mathrm{C}$ in the normal boiling point.

In the case of the monoolefin hydrocarbons, the calculations were made in terms of the difference in the value of the property between a given monoolefin and the corresponding paraffin having the same carbon skeleton, and the required constants were evaluated from data on 58 monoolefins, $\mathrm{C}_{5}$ to $\mathrm{C}_{7}$. For these monoolefins, the average deviation of the calculated from the experimental values is $\pm 0.0031 \mathrm{~g} / \mathrm{ml}$ in density, \pm 0.0020 in refractive index $\left(n_{D}\right.$ at $\left.20^{\circ} \mathrm{C}\right)$, and $\pm 1.33^{\circ} \mathrm{C}$ in the normal boiling point.

\section{CONTENTS}

I. Introduction

II. General method

III. Application to paraffin hydrocarbons _. .

IV. Application to monoolefin hydrocarbons _...

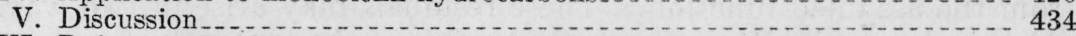

VI. References $\ldots \ldots \ldots \ldots$

\section{INTRODUCTION}

In connection with the work of the American Petroleum Institute Research Project 44 on the "Collection and Analysis of Data on the Properties of Hydrocarbons," at the National Bureau of Standards, it became necessary to make selections of values of the physical properties of refractive index, density, and normal boiling point for

\footnotetext{
1 This investigation was performed at the National Bureau of Standards by the American Petroleum Institute Research Project 44 on the "Collection and Analysis of Data on the Properties of Hydrocarbons." 2 Research Associate on the American Petroleum Institute Research Project 44 at the National Bureat of Standards.
} 
several nonanes and octenes for which no data whatever were available and for several other nonanes and octenes for which the existing data appeared to be rather uncertain. This paper describes the method by which these caculations were made.

It has long been known that the properties of hydrocarbons vary more or less regularly with their molecular structure, and numerous correlations of various properties of hydrocarbons have been made. These include, for example, the graphical methods used by Calingaert and coworkers in connection with molecular volume $[1,2],{ }^{3}$ the structural increment method of Francis in connection with refractive index, density, and normal boiling point [3, 4], and the theoretical method used by Huggins in connection with density and refractive index $[5,6]$. The present investigation follows more nearly the method of Huggins [5] in that, from known values for a considerable number of compounds of a given type, certain constants are evaluated whose appropriate summation permits evaluation of the property for a given hydrocarbon of the same type, with the number of times a given constant is added being determined entirely by the structure of the given molecule.

\section{GENERAL METHOD}

It is frequently desired to correlate a particular property of a group of compounds by fitting an assumed function containing adjustable parameters to the observed values of the property. In the simple case of one independent variable, as the number of carbon atoms in a homologous series of compounds, the method of least squares is often used in the adjustment of the parameter. If the group of compounds is less simply related than a homologous series it is usually necessary to introduce more than one independent variable in order to represent the data adequately.

The advantages of the method of least squares in the multi-dimensional case are essentially the same as in the one dimensional case, namely, the method presents a unique set of values for the parameters based on all the data. In addition, the use of least squares is a relatively rapid method when there are several independent variables, since other methods become increasingly difficult.

The method of least squares is nothing more than a mathematical procedure for minimizing the sum of the squares of the residuals, or the differences between the observed values and the values calculated from the assumed function. These residuals may arise in two ways: (1) the observed values may be in error; (2) the true values will not, in general, satisfy the assumed function perfectly because of the approximate nature of the latter. The relative importance of these two factors depends upon the accuracy of the data and the correctness of the assumed function. If the first effect is predominant, the correlation is essentially a smoothing of the data, and the justification for using least squares is well known. If the second effect is predominant, the correlation is incapable of improving the data, and the interest then is attached to the values of the parameters, which may be used, for example, to calculate approximate values of the property for compounds for which it is unknown. In this case, the justification for the use of least squares is less clear, because the deviation of the true

${ }^{3}$ Figures in brackets indicate the literature references at the end of this paper. 
values from the assumed function is not likely to follow a normal error curve. However, even in this case, a better criterion for the adjustment of the parameters than the minimization of the sum of the squares of the residuals does not seem to be available.

In the applications of least squares to be made here, the independent variables will be free of error, and the normal equations may then be derived very simply. ${ }^{4}$ The derivation will be repeated briefly here in order to introduce the notation adopted and to make certain features of the procedure clear. The language of the physical problem at hand will be used for concreteness.

In a group of $m$ compounds, let the observed value of a given property $G$ be $G_{i}$ for the $i$ th compound. It is desired to represent $G$ by a function of $v$ independent variables $z_{1}, \ldots, z_{v}$, and $t$ adjustable parameters $a_{1}, \ldots, a_{t}$

$$
F=F\left(z_{1}, \ldots, z_{v} ; a_{1}, \ldots, a_{t}\right) .
$$

The variables $z_{1}, \ldots, z_{v}$, are numbers known from the structure of the molecule, for example, the number of atoms or bonds of a given kind; let their values for the $i$ th compound be $z_{1 i}, \ldots, z_{v i}$. The parameters $a_{1}, \ldots, a_{t}$ are to be adjusted to minimize the sum of the weighted squares of the residuals, $\phi^{2}$,

$$
\phi^{2}=\sum_{i=1}^{i=m} w_{i}\left(G_{i}-F_{i}\right)^{2} .
$$

The assignment of weights, $w_{i}$ to the observed values $G_{i}$, will be discussed later. Setting the derivatives of $\phi^{2}$ with respect to $a_{1}, \ldots$, $a_{t}$, equal to zero yields $t$ equations

$$
\sum_{i=1}^{i=m} w_{i} \frac{\partial F_{i}}{\partial a_{s}}\left(G_{i}-F_{i}\right)=0 \quad(s=1, \ldots, t) .
$$

In general, eq 3 are not linear in $a_{1}, \ldots, a_{t}$. Let the (unknown) values of the parameters that satisfy eq 3 be $a_{1}, \ldots, a_{t}$, and assume that in some way approximate values $\bar{a}_{1}, \ldots, \bar{a}_{t}$, have been estimated. Then, neglecting second derivatives of $F$,

$$
\begin{gathered}
F=\bar{F}+\sum_{r=1}^{r=t} \frac{\overline{\partial F}}{\partial a_{\tau}}\left(a_{\tau}-\bar{a}_{\tau}\right)+\ldots \\
\frac{\partial F}{\partial a_{s}}=\frac{\overline{\partial F}}{\partial a_{s}}+\ldots \quad(s=1, \ldots, t),
\end{gathered}
$$

where $\bar{F}$ and $\overline{\partial F / \partial a_{s}}$ are to be evaluated at $a_{1}=\bar{a}_{1}, \ldots, a_{t}=\bar{a}_{t}$. Introducing eq 4 into eq 3 , there is obtained

$$
\sum_{r=1}^{r=t}\left(a_{r}-\bar{a}_{r}\right)\left[\sum_{i=1}^{i=m} w_{i} \frac{\overline{\partial F_{i}}}{\partial a_{\mathrm{r}}} \overline{\frac{\partial F_{i}}{\partial a_{s}}}\right] \cong \sum_{i=1}^{i=m} w_{i} \frac{\overline{\partial F_{i}}}{\partial a_{s}}\left(G_{i}-\bar{F}_{i}\right) \quad(s=1, \ldots, t) .
$$

- For a more general treatment, and for a method of solving the normal equations, see reference [7, chapters IV, VIII, and IX]. 
Equations 5 are the $t$ normal equations, linear in $\left(a_{1}-\bar{a}_{1}\right), \ldots$, $\left(a_{t}-\bar{a}_{t}\right)$. After solving for the latter, $a_{1}, \ldots, a_{t}$ may be calculated. The final values of $a_{1}, \ldots, a_{t}$, will be essentially independent of $\bar{a}_{1}, \ldots, \bar{a}_{t}$, provided the latter are reasonably good estimates. form

In the correlations described in this paper, $F$ has the simple linear

$$
F=\sum_{r=1}^{r=t} a_{r} z_{r} ; \frac{\partial F}{\partial a_{s}}=z_{s} \quad(s=1, \ldots, t),
$$

and the normal equations become

$$
\sum_{r=1}^{r=t}\left(a_{r}-a_{r}\right) \sum_{i=1}^{i=m} w_{i} z_{r i} z_{s i}=\sum_{i=1}^{i=m} w_{i} z_{s i}\left(G_{i}-\bar{F}_{i}\right)(s=1, \ldots, t),
$$

where

$$
\bar{F}=\sum_{r=1}^{r=t} \bar{a}_{r} z_{r}
$$

For this form of $F$ the normal equations are exact, so that solution of eq 7 yields the correct values of $a_{1}, \ldots, a_{t}$, no matter how inaccurate are the estimates $\bar{a}_{1}, \ldots, \bar{a}_{t}$. In particular, if $\bar{a}_{1}=0, \ldots, \bar{a}_{t}=0$, then, also, $\bar{F}=0$, and the normal equations become

$$
\sum_{r=1}^{r=t} a_{r} \sum_{i=1}^{i=m} w_{i} z_{r i} z_{s i}=\sum_{i=1}^{i=m} w_{i} z_{s i} G_{i}(s=1, \ldots, t) .
$$

It may still be advantageous to make estimates $\bar{a}_{1}, \ldots, a_{t}$, and use eq 7 rather than eq 9 , in order to reduce the number of significant figures necessary in the calculations.

After the solution of the normal equations for the parameters $a_{1}$, $\ldots, a_{t}$, the individual deviations, $\left(G_{i}-F_{t}\right)$, may be calculated. For each correlation in this paper there are given one or more of the following: (1) the maximum deviation, or the maximum absolute value of $\left(G_{i}-F_{i}\right) ;(2)$ the average deviation defined by

$$
\text { Average deviation }=\frac{1}{m} \sum_{i=1}^{i=m} w_{i}\left|G_{i}-F_{i}\right|
$$

and (3) the standard deviation of a single value, $\sigma$, defined by

$$
\sigma=\left[\frac{1}{m} \sum_{i=1}^{i=m} w_{i}\left(G_{i}-F_{i}\right)^{{ }^{2}}\right]^{1 / 2}
$$

The assignment of weights, $w$, to the observed values of the property $G$ is not an easy problem. If the uncertainty of the observed value for a given compound is considerably larger than the expected deviation of the true value from the calculated value, a low weight may be assigned to the value for this compound. However there is no justification for assigning a low weight to an accurate value which differs greatly from the calculated value, for the fault lies then with 
the assumed function $F$, rather than with the data. In the correlations described in this report, a single value was first selected for each compound by suitable weighting of the experimental values for each compound; the correlation was then based on these selected values, assigning unit weight $(w=1)$ to each compound included in the correlation.

\section{APPLICATION TO PARAFFIN HYDROCARBONS}

In the application of the present method to the paraffin hydrocarbons, there are several ways in which constants may be assigned to the component parts of the molecule and their interactions. Some of these will be discussed, in the order of increasing complexity.

One of the simplest schemes for the calculation of the properties of the paraffin hydrocarbons, $\mathrm{C}_{n} \mathrm{H}_{2 n+2}$ (where $n$ is the number of carbon atoms), is the assignment of constants $a_{\mathrm{C}}$ and $a_{\mathrm{H}}$ for the contributions of carbon and hydrogen atoms, respectively, to the property $G$. The resulting equation for $G$ is ${ }^{5}$

$$
G=2 a_{\mathrm{H}}+\left(a_{\mathrm{C}}+2 a_{\mathrm{H}}\right) n .
$$

An alternative is the assignment of constants $a_{\mathrm{CC}}$ and $a_{\mathrm{CH}}$ for the contributions of carbon-carbon and carbon-hydrogen bonds, respectively to $G$. The equation for $G$ is then

$$
G=\left(2 a_{\mathrm{CH}}-a_{\mathrm{CC}}\right)+\left(a_{\mathrm{CC}}+2 a_{\mathrm{CH}}\right) n .
$$

If the contributions of both bonds and atoms are included, the equation for $G$ is the sum of the right sides of eq 12 and 13 .

It follows that in each of these cases $G$ takes the form

$$
G=b_{0}+n b \text {, }
$$

so that there are only two adjustable constants. It is also clear that the calculated value of $G$ will be the same for all isomers, since $n$ is the same for isomers.

Perhaps the simplest scheme that is capable of distinguishing isomeric paraffins is the assignment of constants for the contribution to $G$, of $\mathrm{CH}_{3}, \mathrm{CH}_{2}, \mathrm{CH}$, and $\mathrm{C}$ groups, in which the carbon atom is, respectively, primary, secondary, tertiary, and quaternary. Let these constants be $a_{1}, a_{2}, a_{3}$, and $a_{4}$, and let the number of groups of each kind in the $i$ th paraffin be $z_{1 i}, z_{2 i}, z_{3 i}$, and $z_{4 i}$, respectively.

The equation for $G_{i}$ is

$$
G_{i}=z_{1 i} a_{1}+z_{2 i} a_{2}+z_{3 i} a_{3}+z_{4 i} a_{4} .
$$

It is easily seen that the following relations exist between the $z$ 's and $n$, the total number of carbon atoms:

$$
\begin{gathered}
z_{1 i}+z_{2 i}+z_{3 i}+z_{4 i}=n_{i} . \\
3 z_{1 i}+2 z_{2 i}+z_{3 i}=2 n_{i}+2 .
\end{gathered}
$$

${ }^{3}$ Hereafter $G$ will be used to represent both the observed value of the property and the function that represents the property. The meaning intended will always be clear from the context. In section II the property is represented by $G$ and the function by $F$. 
On substitution for $z_{1 i}$ and $z_{2 i}$ from eq 16 and $17, G$ takes the form

$$
G_{i}=\left(2 a_{1}-2 a_{2}\right)+n_{i} a_{2}+z_{3 i}\left(a_{1}-2 a_{2}+a_{3}\right)+z_{4 i}\left(2 a_{1}-3 a_{2}+a_{4}\right) .
$$

Denoting by $G_{n}$ the value of $G$ for the normal paraffin with the same value of $n$, eq 18 reduces to

$$
G_{n}=\left(2 a_{1}-2 a_{2}\right)+n_{i} a_{2} .
$$

Finally, there is obtained for the difference in the value of $G$ between the isomer and the normal paraffin

$$
\Delta G_{i}=\left(G_{i}-G_{n}\right)=z_{3 i}\left(a_{1}-2 a_{2}+a_{3}\right)+z_{4 i}\left(2 a_{1}-3 a_{2}+a_{4}\right) .
$$

Equation 20 has been fitted by least squares (see also section II) to the increment of molal volume at $20^{\circ} \mathrm{C}, \Delta V^{20}$, to the increment of molal refraction for the $D$ line at $20^{\circ} \mathrm{C}, \Delta R_{D}{ }^{20}$, and to the increment of the normal boiling point in degrees, centigrade, $\Delta B P_{760}$ for the 29 branched paraffins (1 pentane, 4 hexanes, 8 heptanes, and 16 octanes) normally liquid at $20^{\circ} \mathrm{C}$ (this excludes the gas, 2,2-dimethylpropane and the solid 2,2,3,3-tetramethylbutane). The data for the calculation of $\Delta V^{20}, \Delta R_{D}{ }^{20}$, and $\Delta B_{760}$ were taken from the selected "best" values of these properties in the tables of the American Petroleum Institute Research Project 44, as of December 31, 1942. The reference values for the normal paraffins are given in table 1, and the difference between the values for the branched paraffins (isoparaffins) and the corresponding normal paraffins are given in table 2 . The molal volume, $V^{20}$, and the molal refraction, $R_{D}{ }^{20}$, are related to the molecular weight, $M$, the density at $20^{\circ} \mathrm{C}, d^{20}$, and the refractive index for the $D$ line at $20^{\circ} \mathrm{C}, n_{D}{ }^{20}$, by the equation

$$
\begin{aligned}
V^{20} & =M / d^{20} . \\
R_{D}{ }^{20} & =\frac{M}{d^{20}}\left[\frac{\left(n_{D}^{20}\right)^{2}-1}{\left(n_{D}{ }^{20}\right)^{2}+2}\right] .
\end{aligned}
$$

TABLE 1.-Reference values for the normal paraffins

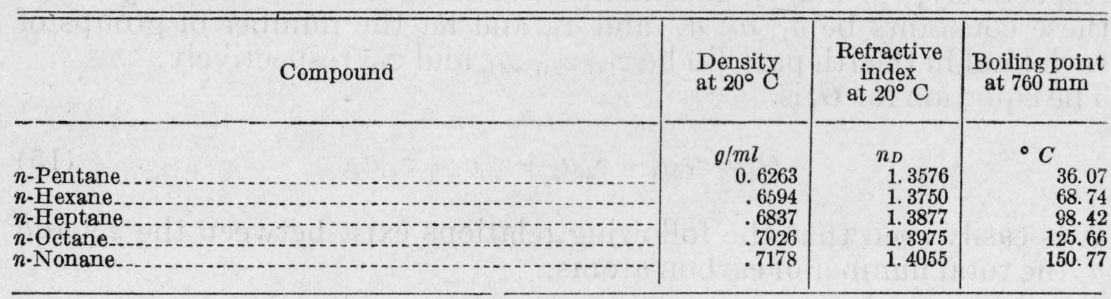


TABLE 2.-Experimental and calculated values of the difference, between each of 29 isoparaffins, $\mathrm{C}_{\mathbf{5}}$ to $\mathrm{C}_{8}$, and the corresponding normal paraffin, of the density, $d$, at $20^{\circ} \mathrm{C}$, the molal volume, $V$, at $20^{\circ} \mathrm{C}$, the refractive index, $n_{D}$, at $20^{\circ} \mathrm{C}$, the molal refraction, $R_{D}$, at $20^{\circ} \mathrm{C}$, and the boiling point, $B P$, at $760 \mathrm{~mm} \mathrm{Hg}$

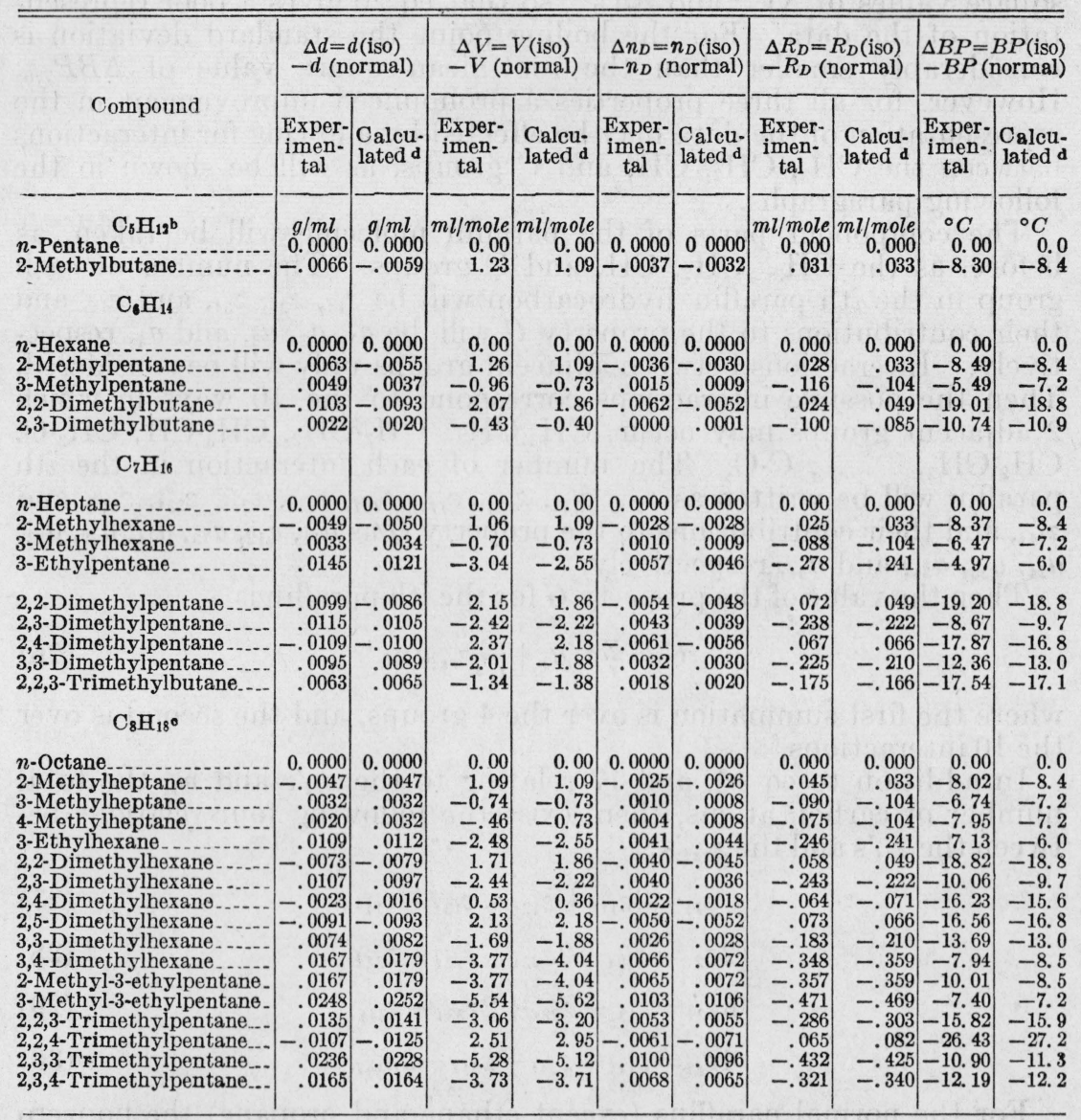

See eq 22.

b 2,2,-Dimethylpropane (neopentane) not included.

- 2,2,3,3-'Tetramethylbutane not included.

d See eq 43 and table 4 .

The final equations, with the standard deviations of a single value, are

$$
\begin{gathered}
\Delta V^{20}=-0.6 z_{3}-0.8 z_{4} \pm 2.3 \\
\Delta R_{D}{ }^{20}=-0.08 z_{3}-0.12 z_{4} \pm 0.15 \\
\Delta B P_{760}=-5.8 z_{3}-13.8 z_{4} \pm 3.9 .
\end{gathered}
$$

The units of $\Delta V^{20}$ and $\Delta R_{D}{ }^{20}$ are milliliters per mole, and $\triangle B P_{760}$ is in degrees centigrade.

The root-mean-square values of $\Delta V^{20}, \Delta R_{D}{ }^{20}$, and $\Delta B P_{760}$ for the 29 paraffins are $\pm 2.51, \pm 0.211$, and \pm 12.9 , as compared with the $638766-45-2$ 
standard deviations from eq 23,24 , and 25 , of $\pm 2.3, \pm 0.15$, and \pm 3.9 , respectively. Thus, for the molal volume and molal refraction, the standard deviations are not much smaller than the root mean square values of $\Delta V^{20}$ and $\Delta R_{D}{ }^{20}$, so that eq 20 gives a poor representation of the data. For the boiling point the standard deviation is considerably smaller than the root-mean-square value of $\triangle B P_{760}$. However, for all three properties a pronounced improvement in the representation of the data may be effected by allowing for interactions between the $\mathrm{CH}_{3}, \mathrm{CH}_{2}, \mathrm{CH}$, and $\mathrm{C}$ groups, as will be shown in the following paragraphs.

The component parts of the paraffin molecule will be taken, as before, as the $\mathrm{CH}_{3}, \mathrm{CH}_{2}, \mathrm{CH}$, and $\mathrm{C}$ groups. The number of each group in the ith paraffin hydrocarbon will be $z_{1 i}, z_{2 i}, z_{3 i}$, and $z_{4 i}$, and their contributions to the property $G$ will be $a_{1}, a_{2}, a_{3}$, and $a_{4}$, respectively. Interactions between adjacent groups only will be considered. Then the possible interactions correspond to the 10 ways in which 2 adjacent groups may occur, $\mathrm{CH}_{3} \cdot \mathrm{CH}_{3}, \mathrm{CH}_{3} \cdot \mathrm{CH}_{2}, \mathrm{CH}_{3} \cdot \mathrm{CH}, \mathrm{CH}_{3} \cdot \mathrm{C}$, $\mathrm{CH}_{2} \cdot \mathrm{CH}_{2}$, ..., C.C. The number of each interaction in the $i$ th paraffin will be written as $z_{11 i}, z_{12 i}, z_{13 i}, z_{14 i}, z_{22 i}, z_{23 i}, z_{24 i}, z_{33 i}, z_{34 i}$, and $z_{44 i}$, and their contributions to the property $G$ as $a_{11}, a_{12}, a_{13}, a_{14}, a_{22}, a_{23}$, $a_{24}, a_{33}, a_{34}$, and $a_{44}$, respectively.

Then the value of the property $G$ for the $i$ th paraffin is

$$
G_{i}=\sum_{r} z_{r i} a_{r}+\sum_{r, s} z_{r s i} a_{r s}
$$

where the first summation is over the 4 groups, and the second is over the 10 interactions. ${ }^{6}$

In addition to eq 16 , and 17 relating to the $z_{r i}$ 's and $n_{i}$, the total number of carbon atoms, there exist the following four relations between the $z_{r i}$ 's and the $z_{r s i}$ 's:

$$
\begin{aligned}
z_{1 i} & =2 z_{11 i}+z_{12 i}+z_{13 i}+z_{14 i} \\
2 z_{2 i} & =z_{12 i}+2 z_{22 i}+z_{23 i}+z_{24 i} \\
3 z_{3 i} & =z_{13 i}+z_{23 i}+2 z_{33 i}+z_{34 i} \\
4 z_{4 i} & =z_{14 i}+z_{24 i}+z_{34 i}+2 z_{44 i} .
\end{aligned}
$$

For the normal paraffins (except ethane and propane) the nonzero $z$ 's are $z_{1}, z_{2}, z_{12}$, and $z_{22}$. It is convenient to eliminate these, and also $\hat{k}_{13}$, and $z_{14}$, by means of eq 16,17 , and eq 27 to 30 . Then eq 26 becomes

$$
G_{i}=b_{0}+n_{i} b+z_{3 i} b_{3}+z_{4 i} b_{4}+z_{11 i} b_{11}+z_{23 i} b_{23}+z_{24 i} b_{24}+z_{33 i} b_{33}+z_{34 i} b_{34}+z_{44 i} b_{44} \text {, }
$$

where the new constants, the $b$ 's, are related to the $a$ 's by the equations

$$
\begin{aligned}
& b_{0}=2 a_{1}-2 a_{2}+2 a_{12}-3 a_{22} \\
& b=a_{2}+a_{22} \\
& b_{3}=a_{1}-2 a_{2}+a_{3}-2 a_{12}+3 a_{13}-a_{22}
\end{aligned}
$$

${ }^{6}$ This is the scheme used by M. L. Huggins [5]. To simplify the problem, Huggins assumed that $a_{13}=a_{22}$,
$a_{14}=a_{23}$, and $a_{24}=a_{33}$. In the present treatment, none of the constants have been eliminated in this manner. $a_{14}=a_{23}$, and $a_{24}=a_{33}$. In the present treatment, none of the constants have been eliminated in this manner. logous series. The least squares treatment used here has the advantage that all the available data is utilized uniformly in fixing the constants. 


$$
\begin{aligned}
& b_{4}=2 a_{1}-3 a_{2}+a_{4}-2 a_{12}+4 a_{14}-2 a_{22} \\
& b_{11}=a_{11}-2 a_{12}+a_{22} \\
& b_{23}=a_{12}-a_{13}-a_{22}+a_{23} \\
& b_{24}=a_{12}-a_{14}-a_{22}+a_{24} \\
& b_{33}=2 a_{12}-2 a_{13}-a_{22}+a_{33} \\
& b_{34}=2 a_{12}-a_{13}-a_{14}-a_{22}+a_{34} \\
& b_{44}=2 a_{12}-2 a_{14}-a_{22}+a_{44} .
\end{aligned}
$$

All the members of a homologous series, except the first, have the same set of values for the $z$ 's in eq 31. This is in qualitative agreement with the anomalous behavior actually observed for the first members of such series. For the remaining members of a homologous series, eq 31 predicts a linear variation of the property $G$ with $n$, with a constant increment per $\mathrm{CH}_{2}$ group of $b$, the same for all series. In particular, for the normal series all the $z$ 's in eq 31 vanish, and

$$
G_{n}=b_{0}+n_{n} b .
$$

From the present viewpoint, ethane (not methane) is the first member of the normal series, and is anomalous, with $G=b_{0}+2 b+b_{11}$. If methane were included in the present scheme, it would be assigned a single and distinct constant, say $a_{0}$.

\begin{tabular}{|c|c|c|}
\hline Member & Compound & $\Delta G$ \\
\hline $\begin{array}{l}\text { First } \\
\text { Second } \\
\text { Third }\end{array}$ & $\begin{array}{l}\text { 2,3-Dimethylbutane } \\
\text { 2,3-Dimethylpentane...... } \\
\text { 2,3-Dimethylhexane-.... }\end{array}$ & $\begin{array}{l}2 b_{3}+b_{33 .} \\
2 b_{3}+b_{33}+b_{23} . \\
2 b_{3}+b_{33}+b_{23} .\end{array}$ \\
\hline
\end{tabular}

By subtraction of eq 42 from eq 31, the difference in value of the property $G$ between the branched chain paraffin and its normal isomer $\left(n_{t}=n_{n}\right)$ is obtained:

$$
\begin{array}{r}
\Delta G_{i}=\left(G_{i}-G_{n}\right)=z_{3 i} b_{3}+z_{4 i} b_{4}+z_{11 i} b_{11}+ \\
z_{23 i} b_{23}+z_{24 i} b_{24}+z_{33 i} b_{33}+z_{34 i} b_{34}+z_{44 i} b_{44} .
\end{array}
$$

\begin{tabular}{|c|c|c|c|c|c|c|c|}
\hline Compound & $z_{3}$ & $z_{4}$ & $z_{23}$ & $z_{24}$ & $z_{33}$ & $z_{34}$ & 24 \\
\hline $\begin{array}{l}\text { n-Pentane } \\
\text { 2-Methylbutane } \mathrm{C}_{52} \\
\text { 2,2-Dimethylpropane }\end{array}$ & $\begin{array}{l}0 \\
1 \\
0\end{array}$ & $\begin{array}{l}0 \\
0 \\
1\end{array}$ & $\begin{array}{l}0 \\
1 \\
0\end{array}$ & $\begin{array}{l}0 \\
0 \\
0\end{array}$ & $\begin{array}{l}0 \\
0 \\
0\end{array}$ & $\begin{array}{l}0 \\
0 \\
0\end{array}$ & $\begin{array}{l}0 \\
0 \\
0\end{array}$ \\
\hline $\begin{array}{l}n-\mathrm{C} \text { - } \mathrm{C}_{6} \mathrm{H}_{14} \\
\text { 2-Methylpentane } \\
\text { 2,-Methylpentane } \\
\text { 2,3-Dimethylbutane }\end{array}$ & $\begin{array}{l}0 \\
1 \\
1 \\
0 \\
2\end{array}$ & $\begin{array}{l}0 \\
0 \\
0 \\
1 \\
0\end{array}$ & $\begin{array}{l}0 \\
1 \\
2 \\
0 \\
0\end{array}$ & $\begin{array}{l}0 \\
0 \\
0 \\
1 \\
0\end{array}$ & $\begin{array}{l}0 \\
0 \\
0 \\
0 \\
1\end{array}$ & $\begin{array}{l}0 \\
0 \\
0 \\
0 \\
0\end{array}$ & $\begin{array}{l}0 \\
0 \\
0 \\
0 \\
0\end{array}$ \\
\hline
\end{tabular}

The term $z_{11 i} b_{11}$ vanishes for all the paraffins except ethane.

As an illustration of eq 43, consider the 2,3-dimethyl series:

The values of the $z$ 's in eq 43 are given in table 3 for each of the 70 paraffin hydrocarbons, $\mathrm{C}_{5}$ to $\mathrm{C}_{9}$.

TABLE 3.-Values of the $z$ 's in equation 43 for each of the 70 paraffins, $\mathrm{C}_{5}$ to $\mathrm{C}_{8}$ 
TABLE 3.-Values of the $z$ 's in equation 43 for each of the 70 parafins, $\mathbf{C}_{5}$ to $\mathrm{C}_{9}$-Continued.

\begin{tabular}{|c|c|c|c|c|c|c|c|}
\hline Compound & $z_{3}$ & $z_{4}$ & $z_{23}$ & $z_{24}$ & $z_{33}$ & $z_{34}$ & $z_{44}$ \\
\hline $\mathrm{C}_{7} \mathrm{H}_{16}$ & & & & & & & \\
\hline 2-Methylhexane. & $\begin{array}{l}0 \\
1\end{array}$ & $\begin{array}{l}0 \\
0\end{array}$ & $\begin{array}{l}0 \\
1\end{array}$ & $\begin{array}{l}0 \\
0\end{array}$ & $\begin{array}{l}0 \\
0\end{array}$ & $\begin{array}{l}0 \\
0\end{array}$ & $\begin{array}{l}0 \\
0\end{array}$ \\
\hline 3-Methylhexane & 1 & 0 & 2 & 0 & 0 & 0 & 0 \\
\hline 3-Ethylpentane & 1 & 0 & 3 & 0 & 0 & 0 & 0 \\
\hline $\begin{array}{l}\text { 2,2-Dimethylpentane } \\
\text { 2,3-Dimethylpentane }\end{array}$ & 0 & 1 & 0 & 1 & & 0 & $\stackrel{0}{0}$ \\
\hline 2,4-Dimethylpentane... & $\begin{array}{l}2 \\
2\end{array}$ & $\begin{array}{l}0 \\
0\end{array}$ & $\begin{array}{l}1 \\
2\end{array}$ & $\begin{array}{l}0 \\
0\end{array}$ & $\begin{array}{l}1 \\
0\end{array}$ & $\begin{array}{l}0 \\
0\end{array}$ & $\stackrel{0}{0}$ \\
\hline 3,3-Dimethylpentane... & 0 & 1 & 0 & 2 & 0 & 0 & 0 \\
\hline 2,2,3-Trimethylbutane & 1 & 1 & 0 & 0 & 0 & 1 & 0 \\
\hline $\mathrm{C}_{8} \mathrm{H}_{18}$ & & & & & & & \\
\hline $\begin{array}{l}n \text {-Octane } \\
\text { 2-Methylheptane. }\end{array}$ & $\begin{array}{l}0 \\
1\end{array}$ & $\begin{array}{l}0 \\
0\end{array}$ & $\begin{array}{l}0 \\
1\end{array}$ & $\begin{array}{l}0 \\
0\end{array}$ & $\begin{array}{l}0 \\
0\end{array}$ & $\begin{array}{l}0 \\
0\end{array}$ & $\begin{array}{l}0 \\
0\end{array}$ \\
\hline 3-Methylheptane...... & 1 & 0 & 2 & 0 & 0 & 0 & 0 \\
\hline $\begin{array}{l}\text { 4-Methylheptane } \\
\text { 3-Ethylhexane. }\end{array}$ & $\begin{array}{l}1 \\
1\end{array}$ & $\begin{array}{l}0 \\
0\end{array}$ & $\begin{array}{l}2 \\
3\end{array}$ & $\begin{array}{l}0 \\
0\end{array}$ & ${ }_{0}^{0}$ & 0 & 0 \\
\hline 2.2-Dimethylhexane & 0 & 1 & 0 & 1 & 0 & 0 & 0 \\
\hline 2,3-Dimethylhexane & 2 & 0 & 1 & 0 & 1 & 0 & 0 \\
\hline 2,4-Dimethylhexane & 2 & 0 & 3 & 0 & 0 & 0 & 0 \\
\hline 2,5-Dimethylhexane... & 2 & 0 & 2 & 0 & 0 & 0 & 0 \\
\hline 3,3-Dimethylhexane & 0 & 1 & 0 & 2 & 0 & 0 & 0 \\
\hline 3,4-Dimethylhexane & 2 & 0 & 2 & 0 & 1 & 0 & 0 \\
\hline 2-Methyl-3-ethylpentane & 2 & 0 & 2 & 0 & 1 & 0 & 0 \\
\hline 3-Methyl-3-ethylpentane. & 0 & 1 & 0 & 3 & 0 & 0 & 0 \\
\hline 2,2,3-Trimethylpentane & 1 & 1 & 1 & 0 & 0 & 1 & 0 \\
\hline $2,2,4$-Trimethylpentane & 1 & 1 & 1 & 1 & 0 & 0 & 0 \\
\hline 2,3,3-Trimethylpentane & 1 & 1 & 0 & 1 & 0 & 1 & 0 \\
\hline 2,3,4-Trimethylpentane & 3 & 0 & 0 & 0 & 2 & 0 & 0 \\
\hline $2,2,3,3$-Tetramethylbutan & 0 & 2 & 0 & 0 & 0 & 0 & 1 \\
\hline $\mathrm{C}_{2} \mathrm{H}_{20}$ & & & & & & & \\
\hline$n$-Nonane & 0 & 0 & 0 & & 0 & 0 & \\
\hline 2-Methyloctane..... & 1 & 0 & 1 & 0 & 0 & 0 & 0 \\
\hline 3-Methyloctane.......... & 1 & 0 & 2 & 0 & 0 & 0 & 0 \\
\hline 4-Methyloctane. & 1 & 0 & 2 & 0 & 0 & 0 & 0 \\
\hline 3-Ethylheptane & 1 & 0 & 3 & 0 & 0 & 0 & 0 \\
\hline 4-Ethlyheptane & 1 & 0 & 3 & 0 & 0 & 0 & 0 \\
\hline 2,2-Dimethylheptane... & 0 & 1 & 0 & 1 & 0 & 0 & 0 \\
\hline 2,3-Dimethylheptane & 2 & 0 & 1 & 0 & 1 & 0 & 0 \\
\hline 2,4-Dimethylheptane & $\overline{2}$ & 0 & 3 & 0 & 0 & 0 & 0 \\
\hline 2,5-Dimethylheptane.-. & 2 & 0 & 3 & 0 & 0 & 0 & 0 \\
\hline 2,6-Dimethylheptane... & 2 & 0 & 2 & 0 & 0 & 0 & 0 \\
\hline 3,3 -Dimethylheptane & $\overline{0}$ & 1 & 0 & 2 & 0 & 0 & 0 \\
\hline 3,4-Dimethylheptane... & 2 & 0 & 2 & 0 & 1 & 0 & 0 \\
\hline 3,5-Dimethylheptane & 2 & 0 & 4 & 0 & 0 & 0 & 0 \\
\hline 4,4-Dimethylheptane & 0 & 1 & 0 & 2 & 0 & 0 & 0 \\
\hline 2-Methyl-3-ethylhexane. & 2 & 0 & 2 & 0 & 1 & 0 & 0 \\
\hline 2-Methyl-4-ethylhexane. & 2 & 0 & 4 & 0 & 0 & 0 & 0 \\
\hline 3-Methyl-3-ethylhexan & 0 & 1 & 0 & 3 & 0 & 0 & 0 \\
\hline 3-Methyl-4-ethylhexane... & 2 & 0 & 3 & 0 & 1 & 0 & 0 \\
\hline 2,2,3-Trimethylhexane... & 1 & 1 & 1 & 0 & 0 & 1 & 0 \\
\hline 2,2,4-Trimethylhexane. & 1 & 1 & 2 & 1 & 0 & 0 & 0 \\
\hline $2,2,5$-Trimethylhexane... & 1 & 1 & 1 & 1 & 0 & 0 & 0 \\
\hline 2,3,3-Trimethylhexane.. & 1 & 1 & 0 & 1 & 0 & 1 & 0 \\
\hline 2,3,4-Trimethylhexane.. & 3 & 0 & 1 & 0 & 2 & 0 & 0 \\
\hline $2,3,5$-Trimethylhexane... & 3 & 0 & 2 & 0 & 1 & 0 & 0 \\
\hline 2,4,4-Trimethylhexane... & 1 & 1 & 1 & 2 & 0 & 0 & 0 \\
\hline 3,3,4-Trimethylhexane... & 1 & 1 & 1 & 1 & 0 & 1 & 0 \\
\hline 3,3-Diethylpentane & 0 & 1 & 0 & 4 & 0 & 0 & 0 \\
\hline 2,2-Dimethyl-3-ethylpentane & 1 & 1 & 2 & 0 & 0 & 1 & 0 \\
\hline 2,3-Dimethyl-3-ethylpentan & 1 & 1 & 0 & 2 & 0 & 1 & 0 \\
\hline 2,4-Dimethyl-3-ethylpentane. & 3 & 0 & 1 & 0 & 2 & 0 & 0 \\
\hline $2,2,3,3$-Tetramethylpentane & 0 & 2 & 0 & 1 & 0 & 0 & 1 \\
\hline $2,2,3,4$-Tetramethylpentane & 2 & 1 & 0 & 0 & 1 & 1 & 0 \\
\hline $2,2,4,4$-Tetramethylpentane... & 0 & 2 & 0 & 2 & 0 & 0 & 0 \\
\hline $2,3,3,4$-Tetramethylpentane... & 2 & 1 & 0 & 0 & 0 & 2 & 0 \\
\hline
\end{tabular}


Equation 43 has been fitted by least squares (see also section II) to the same data as described above for $\Delta V^{20} ; \Delta R_{D}{ }^{20}$, and $\Delta B P_{760}$ for the same 29 branched paraffins, $\mathrm{C}_{5}$ to $\mathrm{C}_{8}$.

The boiling point is not an additive property in the same sense as are the molal volume and the molal refraction. However the degree of correlation of the boiling point is justification for treating it as such. It should be noted that even though $G$ is not strictly linear in $n$ for a normal and a branched homologous series, $\Delta G$ is only slightly affected if the departure from linearity is approximately the same for the two series. Actually $\triangle B P_{760}$ for a homologous series shows a slow decrease with increasing $n$, but this has been disregarded here because of the small range of $n$ involved. $\Delta V$ and $\Delta R$ especially the latter, are nearly constant for a homologous series. The values of the constants $b$ obtained for the paraffin hydrocarbons are shown in table 4 . Since the compound 2,2,3,3-tetramethylbutane was not included in the correlation, the value of $b_{44}$ does not appear in the table. The constants given in table 4 may be used with eq 43 to calculate the difference in molal volume (to give density), molal refraction (to give the refractive index), and normal boiling point, between a normal paraffin hydrocarbon and its isomers.

TABLE 4.-Values of the constants to be used in calculating the difference in mola volume, $\Delta V^{20}$, in molal refraction, $\Delta R_{D^{20}}$, and in normal boiling point, $\Delta B P_{760}$, between a normal paraffin and a given isomer (see eq 43)

\begin{tabular}{|c|c|c|c|}
\hline Constant & For $\Delta V^{20}$ & For $\Delta R_{D^{20}}$ & For $\triangle B P_{700}$ \\
\hline $\begin{array}{l}b_{3} \\
b_{4} \\
b_{23} \\
b_{24} \\
b_{33} \\
b_{34} \\
b_{44}\end{array}$ & $\begin{array}{r}m l / m o l e \\
2.91 \\
5.60 \\
-1.82 \\
-3.74 \\
-6.22 \\
-9.89 \\
-\end{array}$ & $\begin{array}{r}m l / m o l e \\
0.170 \\
.308 \\
-.137 \\
-.259 \\
-.425 \\
-.644\end{array}$ & $\begin{array}{r}{ }^{\circ} C \\
-9.6 \\
-24.6 \\
1.2 \\
5.8 \\
8.3 \\
17.1 \\
\end{array}$ \\
\hline
\end{tabular}

a See eq 22.

The manner in which the 6 constants reproduce, by difference from the corresponding normal paraffin, the data on isopentane, 4 isohexanes, 8 isoheptanes, and 16 isooctanes, is shown in table 2, in which the calculated and experimental values are compared, and is summarized in table 5, which gives the average deviation, the maximum deviation, and the standard deviation, for the molal volume, density, molal refraction, refractive index, and boiling point.

TABLE 5.-Reproducibility of the selected "best" values of molal volume, density, molal refraction, a refractive index, and boiling point, for 29 isoparaffins, $\mathrm{C}_{5}$ to $\mathrm{C}_{8}$, by means of 6 constants evaluated from the selected values (see eq 43)

\begin{tabular}{|c|c|c|c|c|c|}
\hline Deviation & $\begin{array}{l}\text { Molal } \\
\text { volume } \\
\text { at } 20^{\circ} \mathrm{C}\end{array}$ & $\begin{array}{l}\text { Density } \\
\text { at } 20^{\circ} \mathrm{C}\end{array}$ & $\begin{array}{l}\text { Molal re- } \\
\text { fraction } \\
\text { at } 20^{\circ} \mathrm{C}\end{array}$ & $\begin{array}{l}\text { Refractive } \\
\text { index } \\
\text { at } 20^{\circ} \mathrm{C}\end{array}$ & $\begin{array}{c}\text { Boiling } \\
\text { point } \\
\text { at } 760 \mathrm{~mm}\end{array}$ \\
\hline $\begin{array}{l}\text { Average } \\
\text { Maximum } \\
\text { Standard (of a single value) }\end{array}$ & $\begin{array}{r}\mathrm{ml} / \text { mole } \\
\pm 0.16 \\
.49 \\
\pm .20\end{array}$ & $\begin{array}{c}g / m l \\
\pm 0.00074 \\
.0024 \\
\pm .00093\end{array}$ & $\begin{array}{r}m l / m o l e \\
\pm 0.013 \\
.037 \\
\pm .016\end{array}$ & $\begin{aligned} & n_{D} \\
& \pm 0.00042 \\
& .0011 \\
& \pm .00050\end{aligned}$ & $\begin{array}{l}{ }^{\circ} C \\
\quad \pm 0.55 \\
1.71 \\
\pm 0.70\end{array}$ \\
\hline
\end{tabular}

a See eq 22. 
The values of the constants given in table 4 were then used to calculate values of refractive index, density, and boiling point for 33 isononanes (all the branched-chain nonanes except 2,2,3,3-tetramethylpentane which has 2 adjacent neopentyl groups. These values, expressed as the difference between the value for a given isononane and normal nonane, are given in table 6 . For 11 of these isonanes, there were available accurate experimental data on refractive index, density, and boiling point. For these 11 nonanes, the differences between the calculated and experimental values of density, refractive index, and boiling point, using the 6 constants evaluated from the data on the paraffins $\mathrm{C}_{5}$ to $\mathrm{C}_{8}$ (see text and tables 4 and 5 ) are summarized in table 7 .

TABLE 6.-Calculated values of the difference, between each of 33 isononanes and normal nonane, of the density, $d$, at $20^{\circ} \mathrm{C}$, the refractive index, $n_{D}$, at $20^{\circ} \mathrm{C}$, and the boiling point, $B P$, at $760 \mathrm{Hg}$ (see eq 43 and table 4)

\begin{tabular}{|c|c|c|c|}
\hline Compound & $\begin{array}{c}\Delta d=d \text { (iso) }- \\
d(\text { normal })\end{array}$ & $\begin{array}{c}\Delta n_{D}=n_{D} \text { (iso) }- \\
n_{D} \text { (normal) }\end{array}$ & $\begin{array}{c}\Delta B P=B P(\text { iso })- \\
B P(\text { normal })\end{array}$ \\
\hline $\begin{array}{l}n-\mathrm{N} o n a n e \\
\text { 3-Methyloctane } \\
\text { 3-Methyloctane } \\
\text { 4-Ethylhectane }\end{array}$ & $\begin{array}{r}g / m l \\
0.0000 \\
-.0043 \\
.0029 \\
.0029 \\
.0104 \\
.0104\end{array}$ & $\begin{array}{r}0.0000 \\
-.0024 \\
.0008 \\
.0008 \\
.0041 \\
.0041\end{array}$ & $\begin{array}{r}{ }^{\circ} C \\
0.0 \\
-8.4 \\
-7.2 \\
-7.2 \\
-6.0 \\
-6.0\end{array}$ \\
\hline $\begin{array}{l}\text { 2,2-Dimethylheptane. } \\
\text { 2,3-Dimethylheptane } \\
\text { 2,4-Dimethylheptane } \\
\text { 2,5-Dimethylheptane } \\
\text { 3,3-Dimethylheptane } \\
\text { 3,4-Dimethylheptane } \\
\text { 3,5-Dimethylheptane } \\
\text { 4,4-Dimethylheptane }\end{array}$ & $\begin{array}{r}-.0074 \\
.0090 \\
-.0014 \\
-.0014 \\
-.0086 \\
.0076 \\
.0166 \\
.0059 \\
.0076\end{array}$ & $\begin{array}{r}-.0042 \\
.0034 \\
-.0017 \\
-.0017 \\
-.0049 \\
.0027 \\
.0068 \\
.0016 \\
.0027\end{array}$ & $\begin{array}{r}-18.8 \\
-9.7 \\
-15.6 \\
-15.6 \\
-16.8 \\
-13.0 \\
-8.5 \\
-14.4 \\
-13.0\end{array}$ \\
\hline $\begin{array}{l}\text { 2-Methyl-3-ethylhexane } \\
\text { 2-Methyl-4-ethylhexane } \\
\text { 3-Methyl-3-ethylhexane } \\
\text { 3-Methyl-4-ethylhexane }\end{array}$ & $\begin{array}{l}.0166 \\
.0059 \\
.0233 \\
.0243\end{array}$ & $\begin{array}{l}.0068 \\
.0016 \\
.0099 \\
.0102\end{array}$ & $\begin{array}{r}-8.5 \\
-14.4 \\
-7.2 \\
-7.3\end{array}$ \\
\hline $\begin{array}{l}\text { 2,2,3-Trimethylhexane } \\
\text { 2,2,4-Trimethylhexane } \\
\text { 2,2,5-Trimethylhexane } \\
\text { 2,3,3-Trimethylhexane } \\
\text { 2,3,5-Trimethylhexane } \\
\text { 2,4,4-Trimethylhexane } \\
\text { 3,3,4-Trimethylhexane }\end{array}$ & $\begin{array}{r}.0131 \\
-.0045 \\
-.0117 \\
.0212 \\
0229 \\
.0046 \\
.0032 \\
.0290\end{array}$ & $\begin{array}{r}.0051 \\
-.0035 \\
-.0066 \\
.0090 \\
.0095 \\
.0009 \\
.0002 \\
.0125\end{array}$ & $\begin{array}{l}-15.9 \\
-26.0 \\
-27.2 \\
-11.3 \\
-11.0 \\
-18.1 \\
-21.4 \\
-10.1\end{array}$ \\
\hline $\begin{array}{l}\text { 3,3-Diethylpentane } \\
\text { 2,2-Dimethyl-3-ethylpentane } \\
\text { 2,3-Dimethy]-3-ethylpentane } \\
\text { 2,4-Dimethyl-3-ethylpentane } \\
\text { 2,2,3,4-Tetramethylpentane } \\
\text { b 2,2,4,4-Tetramethylpentane } \\
\text { 2,3,3,4-Tetramethylpentane }\end{array}$ & $\begin{array}{r}.0397 \\
.0208 \\
.0375 \\
.0229 \\
.0194 \\
-.0146 \\
.0352\end{array}$ & $\begin{array}{r}.0175 \\
.0086 \\
.0165 \\
.0095 \\
.0079 \\
-.0084 \\
.0156\end{array}$ & $\begin{array}{r}-1.4 \\
-14.7 \\
-5.5 \\
-11.0 \\
-18.4 \\
-37.6 \\
-9.6\end{array}$ \\
\hline
\end{tabular}

- 2,2,3,3-Tetramethylpentane not included.

b See section V.

TABLE 7.-Differences between calculated and experimental values of density, refractive index, and boiling point, for 11 branched-chain nonanes for which accurate experimental data were available (see eq 43)

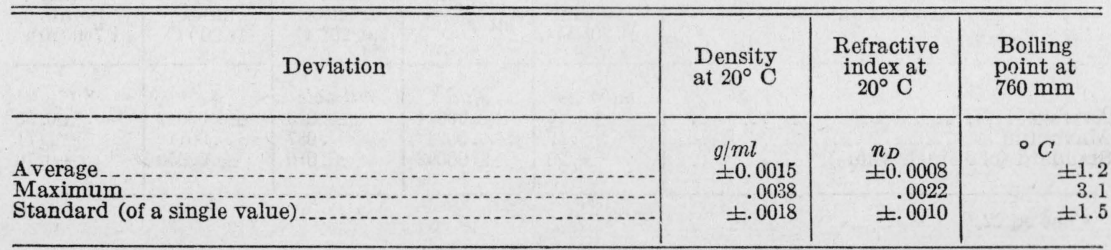


The constants given in table 4 may be used with eq 43 to calculate by difference from the corresponding normal isomer, values of refractive index, density, and boiling point for the higher paraffins (including decanes, undecanes, dodecanes, etc.), except those having two neopentyl groups once (adjacent) or twice removed from each other. The values of density and refractive index would apply, of course, to the liquid state at $20^{\circ} \mathrm{C}$. (However, in calculating boiling points, allowance should be made for the slow decrease of $\Delta B P_{760}$ for a homologous series with increasing number of carbon atoms.)

After the values of the constants, the $b$ 's, have been obtained by the correlation of the data $\left(b_{0}\right.$ and $b$ may be obtained from the limiting linear relation approached by the normal series), it is of considerable interest to inquire how much information may be obtained concerning the original constants characterizing the component parts and interactions of the molecule, the $a$ 's. It should be remembered that the $b$ 's are to some extent arbitrary, since they depend upon which $z$ 's are eliminated from eq 26 . This latitude does not, of course, affect the correlation of the data or the values calculated from the constants. However, from a fundamental viewpoint, the $a$ 's are more simply defined and of more interest than the $b$ 's.

First, it is clear that eq 32 to 35 may be solved for $a_{1}, a_{2}, a_{3}$, and $a_{4}$, provided the $a_{r s}$ 's (interactions) are known. For the determination of the $10 a_{r s}$ 's there are available only six equations, 36 to 41 . Actually, in the present case, only four equations, 37 to 40 , are available for the determination of $8 a_{r s}$ 's, since $b_{11}$ and $b_{44}$ were not determined. Therefore, it is not possible to determine the $a_{r s}$ 's without the introduction of some additional conditions. The reasonable assumption that will be made is that $a_{r s}$ is a simple function of the indices $r$ and $s$, so that it may be represented by a few terms of a power series (symmetrical) in $r$ and $s:{ }^{7}$

$$
\begin{aligned}
a_{r s}=\left(h_{0}+h_{1} r+h_{2} r^{2}+\ldots\right)+\left(h_{0}+h_{1} s+h_{2} s^{2}+\underset{ }{\left[k_{1}(r s)+k_{2}\left(r^{2} s+r s^{2}\right)\right.}+\ldots .\right. & .
\end{aligned}
$$

Furthermore, only the cross-terms between $r$ and $s$ need be retained, since the terms in powers of $r$ alone and $s$ alone, may always be assigned to $a_{r}$ and $a_{s}$, respectively (that is, only the cross-terms represent true "interactions"). Therefore, $a_{r s}$ may be written

$$
a_{r s}=k_{1}(r s)+k_{2}\left(r^{2} s+r s^{2}\right)+\ldots
$$

On substitution of eq 45 into eq 36 to 41 , there are obtained the following set of equations for the determination of $k_{1}, k_{2}, \ldots$ (it may be remarked that the terms in eq 44 in $r$ alone, and $s$ alone, would vanish in this substitution):

$$
\begin{aligned}
& b_{11}=k_{1}+6 k_{2}+\ldots \\
& b_{23}=k_{1}+8 k_{2}+\cdots \\
& b_{24}=2 k_{1}+18 k_{2}+\cdots \\
& b_{33}=3 k_{1}+26 k_{2}+\cdots \\
& b_{34}=5 k_{1}+48 k_{2}+\ldots \\
& b_{44}=8 k_{1}+84 k_{2}+\ldots
\end{aligned}
$$
${ }^{7}$ However, it should be recognized that the assignment of the indices $1,2,3$, and 4 to the $\mathrm{CH}_{3}, \mathrm{CH}_{2}, \mathrm{CH}$,
and $\mathrm{C}$ groups is arbitrary. Any linear transformation of the indices, of the form $r^{\prime}=\alpha+\beta r, s^{\prime}=\alpha+\beta s$ yields an equally valid set of indices. If $a_{r}$ is expanded in a power series in the generalized indices, $r^{\prime}$ and $s^{\prime}$. and $r^{\prime}$ and $\boldsymbol{s}^{\prime}$ are then replaced by $(\alpha+\beta r)$ and $(\alpha+\beta s)$, powers series of the same form as eq 44 and 45 , are $r^{\prime}$ and $s^{\prime}$ are then replaced by $(\alpha+\beta r)$ and $(\alpha+\beta s)$, powers series of the same form as eq 44 and 45 , are
obtained, but $h_{0}, h_{1}, h_{2}, \ldots$, and $k_{1}, k_{2}, \ldots$, become functions of $\alpha$ and $\beta$. However, it is obvious that the values of the numerical coefficients in eq 46 to 51 , which are the essential result of the present discussion, are unchanged. 
It has been found that when the $b$ 's from table 4 , for $\Delta V^{20}, \Delta R_{D}{ }^{20}$, and $\triangle B P_{760}$ are substituted in eq 47 to 50 , these four equations are approximately satisfied when only the first constant $k_{1}$, is retained. Very little improvement is effected by retaining also $k_{2}$. Thus, if only $k_{1}$ is retained, the least-squares value of $k_{1}$ is

$$
k_{1}=\left(\frac{b_{23}+2 b_{24}+3 b_{33}+5 b_{34}}{1^{2}+2^{2}+3^{2}+5^{2}}\right)
$$

and the calculated values are

\begin{tabular}{|c|l|}
\hline \multicolumn{1}{|c|}{ Property } & \multicolumn{1}{c|}{ Value of $k_{1}$} \\
\hline$\Delta V^{20}$ & $-1.98 \mathrm{ml} / \mathrm{mole}$. \\
$\Delta R_{n^{20}}$ & $-0.132 \mathrm{ml} / \mathrm{mole}$ \\
\hline$B P_{760}$ & $3.2^{\circ} \mathrm{C}$ \\
\hline
\end{tabular}

The values of the $b$ 's calculated from these values of $k_{1}$ are compared with the observed values in table 8 . The agreement is not as good for $\Delta B P_{760}$ as for $\Delta V^{20}$ and $\Delta R_{D}{ }^{20}$.

TABLE 8.-Comparison of the observed values of the constants (b's) and the values calculated from the first term of equations 46 to 51

\begin{tabular}{|c|c|c|c|c|c|c|}
\hline \multirow{2}{*}{ Constant } & \multicolumn{2}{|c|}{$\Delta V^{20}$} & \multicolumn{2}{|c|}{$\Delta R_{D^{20}}$} & \multicolumn{2}{|c|}{$\Delta B P_{780}$} \\
\hline & Observed & Calculated & Observed & Calculated & Observed & Calculated \\
\hline$b_{11} b_{23}$ & $\begin{array}{r}\text { ml/mole } \\
-1.82 \\
-3.74 \\
-6.22 \\
-9.89 \\
\end{array}$ & $\begin{array}{r}m l / m o l e \\
-1.98 \\
-1.98 \\
-3.96 \\
-5.94 \\
-9.90 \\
-15.84\end{array}$ & $\begin{array}{r}\mathrm{ml} / \mathrm{mole} \\
-0.137 \\
-.259 \\
-.425 \\
-.644\end{array}$ & $\begin{array}{r}m l / m o l e \\
-0.132 \\
-.132 \\
-.264 \\
-.396 \\
-.660 \\
-1.056\end{array}$ & $\begin{array}{r}{ }^{\circ} \mathrm{C} \\
1.2 \\
5.8 \\
8.3 \\
17.1\end{array}$ & $\begin{array}{r}{ }^{\circ} \mathrm{C} \\
3.16 \\
3.16 \\
6.32 \\
9.48 \\
15.80 \\
25.28\end{array}$ \\
\hline
\end{tabular}

- See eq 22.

\section{APPLICATION TO MONOOLEFIN HYDROCARBONS}

In applying the present method to the monoolefins, the quantity correlated was the value of the given property for a given monoolefin less the value for the parent paraffin. This difference will be denoted by $\Delta G$. The parent paraffin hydrocarbon is defined as the paraffin with the same carbon skeleton as the olefin; in other words, replacement of the double bond in an olefin by a single bond yields the parent paraffin hydrocarbon. Obviously several olefins may have the same parent paraffin.

This approach is useful because the data on the paraffin hydrocarbons are more complete and more accurate than the data on the monoolefins. Thus the data on the octanes, which are now complete, provide the basis for the calculation of the properties of the octenes, for many of which the data are missing or quite inaccurate.

In the correlation of the paraffin hydrocarbons the Lorentz molal refraction, defined by eq 22 , was used. Because of the labor involved in calculating the Lorentz refraction, it was decided in the case of the monoolefins to use the Gladstone-Dale type of molal refraction, 


$$
R_{D}{ }^{20}=\frac{M}{d^{20}}\left(n_{D}{ }^{20}-1\right),
$$

which was used by Huggins [5, 6]. It is probable that in either case the correlation leads to essentially the same calculated refractive indices.

The correlation of the increment of the molal volume at $20^{\circ} \mathrm{C}$, $\Delta V^{20}$, the increment of the molal refraction for the $D$ line at $20^{\circ} \mathrm{C}$, $\Delta R_{D}{ }^{20}$, and the increment of the boiling point at $760 \mathrm{~mm}, \Delta B P_{760}$, has been carried out for 58 monoolefins, $\mathrm{C}_{5}$ to $\mathrm{C}_{7}$ (the only compound of the 59 in the $\mathrm{C}_{5}$ to $\mathrm{C}_{7}$ range omitted was 3,4-dimethyl-1-pentene, for which no data were available to the authors).

The values of these properties for the monoolefins, and for the parent paraffin hydrocarbons $\left(\mathrm{C}_{5}\right.$ to $\left.\mathrm{C}_{7}\right)$, were taken from the tables of the American Petroleum Institute Research Project 44 as of September 30, 1943.

These data, expressed as the difference between the values for a given monoolefin and the corresponding paraffin with the same carbon skeleton, are given in table 9 .

The simplest scheme for the correlation of $\Delta G$ would be the assignment of a single constant for the contribution of the double bond. The least squares value of the constant is then the average value of $\Delta G$ for the 58 monoolefins. The average value of $\Delta V^{20}, \Delta R_{D}{ }^{20}$, and $\Delta B P_{760}$ are shown in table 10 , together with the maximum deviation of a single value, and the standard deviation (of a single value).

In order to improve the representation of the data, the double bonds may be divided into classes in a suitable way, and a constant assigned to each class. The classification chosen here depends on the number and location of the attached alkyl groups (indicated by $\mathrm{R}$ ), as shown below: 8

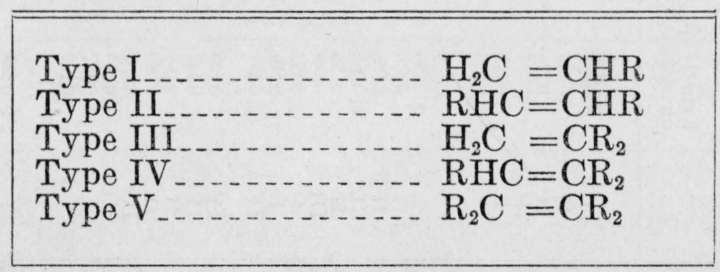

In each type except type $I$ it is possible for geometrical (cis- and trans-) isomers to occur, with comparatively small differences in physical properties. In all the present calculations geometrical isomers were treated as distinct compounds (of the same class), so that the constants derived refer to an average value for cis- and trans-isomers. The same result would be obtained by averaging the properties of the two isomers and then giving it a weight of two in the calculations. The decision not to distinguish cis- and trans-isomers in the calculations was made because the cis-trans difference does not appear to be very regular, and is, for all except a few compounds, of the same order as the uncertainty of the experimental data.

The average values of $\Delta V^{20}, \Delta R_{D}^{20}$, and $\Delta B P_{760}$ for each of the five

\footnotetext{
${ }^{8}$ See reference [8] and the references given therein.
}

$638766-45-3$ 
$\mathrm{T}_{\mathrm{ABLE}}$ 9.- Experimental and calculated values of the difference, between each of 58 monoolefins, $\mathrm{C}_{5}$ to $\mathrm{C}_{7}$, and the corresponding paraffin having the same carbon skeleton, of the density $d$, at $20^{\circ} \mathrm{C}$, the molal volume, $V$, at $20^{\circ} \mathrm{C}$, the refractive index, $n_{D}$, at $20^{\circ} \mathrm{C}$, the molal refraction, a $R_{D}$, at $20^{\circ} C$, and the boiling point, $B P$, at $760 \mathrm{~mm} \mathrm{Hg}$

\begin{tabular}{|c|c|c|c|c|c|c|c|c|c|c|c|}
\hline \multirow{2}{*}{ Compound } & \multirow{2}{*}{ Type } & \multicolumn{2}{|c|}{$\Delta d^{20}$} & \multicolumn{2}{|c|}{$\Delta V^{20}$} & \multicolumn{2}{|c|}{$\Delta n_{D}^{20}$} & \multicolumn{2}{|c|}{$\Delta R_{D}^{20}$} & \multicolumn{2}{|c|}{$\triangle B P_{76 \theta}$} \\
\hline & & $\begin{array}{l}\text { Experi- } \\
\text { mental }\end{array}$ & Calculated o & $\begin{array}{l}\text { Experi- } \\
\text { mental }\end{array}$ & Calculated $\circ$ & $\begin{array}{l}\text { Experi- } \\
\text { mental }\end{array}$ & Calculated o & $\begin{array}{l}\text { Experi- } \\
\text { mental }\end{array}$ & Caleulated o & $\begin{array}{l}\text { Experi- } \\
\text { mental }\end{array}$ & Calculated ${ }^{\circ}$ \\
\hline 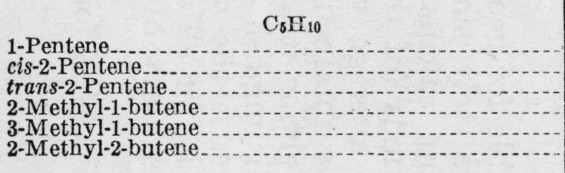 & $\begin{array}{c}\text { I } \\
\text { II } \\
\text { II } \\
\text { III } \\
\text { IV }\end{array}$ & $\begin{array}{r}\text { g/mil } \\
0.0153 \\
.0298 \\
.0228 \\
.0307 \\
.0075 \\
.0425\end{array}$ & $\begin{array}{c}g / \text { mil } \\
0.0131 \\
.0256 \\
.0256 \\
.0284 \\
.0054 \\
0359\end{array}$ & $\begin{array}{r}m l / m o l e \\
-5.89 \\
-8.30 \\
-7.15 \\
-8.59 \\
-4.56 \\
-10.52\end{array}$ & $\begin{array}{l}m l / m o l e \\
-5.52 \\
-7.61 \\
-7.61 \\
-8.21 \\
-4.18 \\
-9.45\end{array}$ & $\begin{array}{r}0.0135 \\
.0245 \\
.0220 \\
.0240 \\
.0106 \\
.0336\end{array}$ & $\begin{array}{r}0.0129 \\
.0221 \\
.0221 \\
.0220 \\
.0106 \\
.0283\end{array}$ & $\begin{array}{r}m l / m o l e \\
-0.63 \\
-.35 \\
-.18 \\
-1.17 \\
-0.34 \\
-.16\end{array}$ & $\begin{array}{r}m l / m o l e \\
-0.56 \\
-.35 \\
-.35 \\
-.53 \\
-.72 \\
-.32\end{array}$ & $\begin{array}{r}\circ C \\
-5.98 \\
0.92 \\
-.08 \\
3.24 \\
-7.71 \\
10.54\end{array}$ & $\begin{array}{r}{ }^{\circ} C \\
-5.06 \\
0.00 \\
.00 \\
1.92 \\
-9.02 \\
5.63\end{array}$ \\
\hline 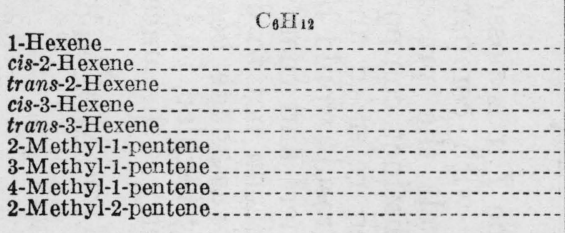 & $\begin{array}{l}\text { I } \\
\text { II } \\
\text { II } \\
\text { II } \\
\text { II } \\
\text { III } \\
\text { I } \\
\text { I } \\
\text { IV }\end{array}$ & $\begin{array}{l}0.0156 \\
.0246 \\
.0196 \\
.0196 \\
.0186 \\
.0289 \\
.0057 \\
.0119 \\
.0359\end{array}$ & $\begin{array}{l}0.0130 \\
.0244 \\
.0244 \\
.0186 \\
.0186 \\
.0271 \\
.0061 \\
.0126 \\
.0281\end{array}$ & $\begin{array}{l}-6.00 \\
-7.64 \\
-6.74 \\
-6.74 \\
-6.56 \\
-8.54 \\
-4.11 \\
-5.39 \\
-9.80\end{array}$ & $\begin{array}{l}-5.52 \\
-7.61 \\
-7.61 \\
-6.56 \\
-6.56 \\
-8.21 \\
-4.18 \\
-5.52 \\
-8.40\end{array}$ & $\begin{array}{r}0.0131 \\
.0206 \\
.0186 \\
.0186 \\
.0191 \\
.0211 \\
.0070 \\
.0126 \\
.0289\end{array}$ & $\begin{array}{l}0.0120 \\
.0203 \\
.0203 \\
.0183 \\
.0183 \\
.0203 \\
.0068 \\
.0118 \\
.0239\end{array}$ & $\begin{array}{r}-0.61 \\
-.33 \\
-.22 \\
-.22 \\
-.09 \\
-.57 \\
-.67 \\
-.40 \\
-.11\end{array}$ & $\begin{array}{l}-0.56 \\
-.35 \\
-.35 \\
-.19 \\
-.19 \\
-.53 \\
-.72 \\
-.56 \\
-.16\end{array}$ & $\begin{array}{r}-5.24 \\
-0.14 \\
-.74 \\
-1.34 \\
-0.74 \\
1.93 \\
-9.48 \\
-6.27 \\
6.93\end{array}$ & $\begin{array}{r}-5.06 \\
0.00 \\
.00 \\
-1.60 \\
-1.60 \\
1.92 \\
-9.02 \\
-5.06 \\
4.03\end{array}$ \\
\hline $\begin{array}{l}\text { cis(?)-3-Methyl-2-pentene } \\
\text { trans(?)-3-Methyl-2-pentene } \\
\text { cis(?)-4-Methyl-2-pentene } \\
\text { trans }(?)-4-M e t h y l-2-p e n t e n e \\
\text { 2-Ethyl-1-butene } \\
\text { 2,3-Dimethyl-1-butene-2 } \\
\text { 3,3-Dimethyl-1-butene } \\
\text { 2,3-Dimethyl-2-butene }\end{array}$ & $\begin{array}{l}\text { IV } \\
\text { IV } \\
\text { II } \\
\text { II } \\
\text { III } \\
\text { III } \\
\text { I } \\
\text { V }\end{array}$ & $\begin{array}{l}.0299 \\
.0343 \\
.0189 \\
.0189 \\
.0252 \\
.0164 \\
.0037 \\
.0472\end{array}$ & $\begin{array}{l}.0294 \\
.0294 \\
.0166 \\
.0166 \\
.0224 \\
.0205 \\
.0036 \\
.0426\end{array}$ & $\begin{array}{l}-8.49 \\
-9.26 \\
-6.71 \\
-6.71 \\
-7.67 \\
-6.13 \\
-3.84 \\
-11.52\end{array}$ & $\begin{array}{r}-8.40 \\
-8.40 \\
-6.27 \\
-6.27 \\
-7.16 \\
-6.87 \\
-3.82 \\
-10.74\end{array}$ & $\begin{array}{l}.0251 \\
.0280 \\
.0176 \\
.0176 \\
.0205 \\
.0152 \\
.0072 \\
.0371\end{array}$ & $\begin{array}{l}.0248 \\
.0248 \\
.0145 \\
.0145 \\
.0190 \\
.0152 \\
.0080 \\
.0346\end{array}$ & $\begin{array}{l}-.15 \\
-.11 \\
-.29 \\
-.29 \\
-.39 \\
-.41 \\
-.48 \\
.09\end{array}$ & $\begin{array}{l}-.16 \\
-.16 \\
-.51 \\
-.51 \\
-.37 \\
-.69 \\
-.38 \\
.11\end{array}$ & $\begin{array}{r}4.52 \\
7.22 \\
-4.27 \\
-1.77 \\
1.72 \\
-2.37 \\
-8.50 \\
15.26\end{array}$ & $\begin{array}{r}4.03 \\
4.03 \\
-3.96 \\
-3.96 \\
0.32 \\
-2.04 \\
-8.81 \\
12.03\end{array}$ \\
\hline 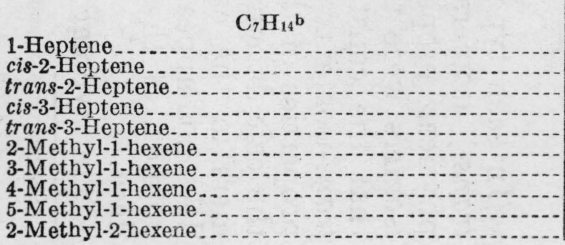 & $\begin{array}{c}\text { I } \\
\text { II } \\
\text { II } \\
\text { II } \\
\text { II } \\
\text { III } \\
\text { I } \\
\text { I } \\
\text { I } \\
\text { IV }\end{array}$ & $\begin{array}{r}0.0133 \\
.0243 \\
.0203 \\
.0183 \\
.0173 \\
.0212 \\
.0080 \\
.0099 \\
.0152 \\
.0302\end{array}$ & $\begin{array}{l}0.0125 \\
.0230 \\
.0230 \\
.0177 \\
.0177 \\
.0255 \\
.0060 \\
.0127 \\
.0122 \\
.0265\end{array}$ & $\begin{array}{l}-5.69 \\
-7.87 \\
-7.09 \\
-6.69 \\
-6.49 \\
-7.35 \\
-4.58 \\
-4.97 \\
-6.14 \\
-9.13\end{array}$ & $\begin{array}{l}-5.52 \\
-7.61 \\
-7.61 \\
-6.56 \\
-6.56 \\
-8.21 \\
-4.18 \\
-5.52 \\
-5.52 \\
-8.40\end{array}$ & $\begin{array}{r}0.0117 \\
.0183 \\
.0183 \\
.0163 \\
.0163 \\
.0191 \\
.0083 \\
.0098 \\
.0111 \\
.0251\end{array}$ & $\begin{array}{c}0.0112 \\
.0187 \\
.0187 \\
.0168 \\
.0168 \\
.0189 \\
.0063 \\
.0112 \\
.0110 \\
.0221\end{array}$ & $\begin{array}{r}-0.56 \\
-.52 \\
-.20 \\
-.32 \\
-.24 \\
=.15 \\
-.61 \\
-.55 \\
-.80 \\
-.04\end{array}$ & $\begin{array}{l}-0.56 \\
-.35 \\
-.35 \\
-.19 \\
-.19 \\
-.53 \\
-.72 \\
-.56 \\
-.56 \\
-.16\end{array}$ & $\begin{array}{r}-5.13 \\
0.07 \\
-.43 \\
-2.63 \\
-2.63 \\
1.25 \\
-7.95 \\
-4.65 \\
-4.55 \\
4.45\end{array}$ & $\begin{array}{r}-5.06 \\
0.00 \\
.00 \\
-1.60 \\
-1.60 \\
1.92 \\
-9.02 \\
-5.06 \\
-5.06 \\
4.03\end{array}$ \\
\hline
\end{tabular}


cis-3-Methyl-2-hexene...

crans-3-Methyl-2-hexene

(rans-4-Methyl-2-hexen-

cis-5-Methyl-2-hexene

rans-5-Methyl-2-hexene

cis-2-Methyl-3-hexene

rans-2-Methyl-3-hexene

trans-3-Methyl-3-hexe

2-Ethyl-1-pentene

2,3-Dimethyl-1-pentene

2,4-Dimethyl-1-pentene

3,3-Dimethyl-1-pentene

4,4-Dimethyl-1-pentene

2,3-Dimethyl-2-pentene.

4-Dimethyl-2-pentene

tran-1

cis-4,4-Dimethyl-2-pentenen

trans-4-4-Dimethyl-2-pentene

3-Methyl-2-ethyl-1-butene

\begin{tabular}{|c|c|c|c|c|c|c|c|c|c|c|}
\hline $\begin{array}{l}\text { IV } \\
\text { IV } \\
\text { II } \\
\text { II } \\
\text { II } \\
\text { II } \\
\text { II } \\
\text { II } \\
\text { IV } \\
\text { IV }\end{array}$ & $\begin{array}{l}.0250 \\
.0250 \\
.0130 \\
.0110 \\
.0212 \\
.0212 \\
.0152 \\
.0152 \\
.0160 \\
.0160\end{array}$ & $\begin{array}{l}.0273 \\
.0273 \\
.0164 \\
.0164 \\
.0225 \\
.0225 \\
.0107 \\
.0107 \\
.0219 \\
.0219\end{array}$ & $\begin{array}{l}-7.95 \\
-7.95 \\
-5.59 \\
-5.19 \\
-7.35 \\
-7.35 \\
-6.14 \\
-6.14 \\
-6.19 \\
-6.19\end{array}$ & $\begin{array}{l}-8.40 \\
-8.40 \\
-6.27 \\
-6.27 \\
-7.61 \\
-7.61 \\
-5.22 \\
-5.22 \\
-7.35 \\
-7.35\end{array}$ & $\begin{array}{l}.0213 \\
.0213 \\
.0103 \\
.0103 \\
.0151 \\
.0151 \\
.0141 \\
.0141 \\
.0183\end{array}$ & $\begin{array}{l}.0226 \\
.0226 \\
.0138 \\
.0138 \\
.0185 \\
.0185 \\
.0117 \\
.0117 \\
.0206 \\
.0206\end{array}$ & $\begin{array}{r}-.15 \\
-.15 \\
-.73 \\
-.57 \\
-.72 \\
=.72 \\
-.37 \\
-.37 \\
.15 \\
.15\end{array}$ & $\begin{array}{r}-.16 \\
-.16 \\
-.51 \\
=.51 \\
-.35 \\
-.35 \\
-.35 \\
-.35 \\
.00 \\
.00\end{array}$ & $\begin{array}{r}1.55 \\
1.55 \\
-4.95 \\
-6.45 \\
-0.55 \\
-2.55 \\
-3.05 \\
-3.05 \\
2.05 \\
2.05\end{array}$ & $\begin{array}{r}4.03 \\
4.03 \\
-3.96 \\
-3.96 \\
0.00 \\
.00 \\
-5.56 \\
-5.56 \\
2.43 \\
2.43\end{array}$ \\
\hline $\begin{array}{c}\text { III } \\
\text { I } \\
\text { III } \\
\text { III } \\
\text { I } \\
\text { I } \\
\text { IV }\end{array}$ & $\begin{array}{r}.0210 \\
-.0012 \\
.0104 \\
.0210 \\
.0032 \\
.0111 \\
.0218\end{array}$ & $\begin{array}{l}.0209 \\
.0065 \\
.0201 \\
.0250 \\
.0045 \\
.0119 \\
.0229\end{array}$ & $\begin{array}{l}-7.17 \\
-2.65 \\
-4.98 \\
-7.41 \\
-3.56 \\
-5.35 \\
-7.15\end{array}$ & $\begin{array}{l}-7.16 \\
-4.18 \\
-6.87 \\
-8.21 \\
-3.82 \\
-5.52 \\
-7.35\end{array}$ & $\begin{array}{l}.0163 \\
.0046 \\
.0100 \\
.0154 \\
.0075 \\
.0097 \\
.0196\end{array}$ & $\begin{array}{l}.0174 \\
.0066 \\
.0146 \\
.0185 \\
.0079 \\
.0108 \\
.0212\end{array}$ & $\begin{array}{r}-0.52 \\
-.40 \\
-.56 \\
-.65 \\
-.34 \\
-.66 \\
-.14\end{array}$ & $\begin{array}{r}-0.37 \\
-.72 \\
-.69 \\
-.53 \\
-.38 \\
-.56 \\
.00\end{array}$ & $\begin{array}{r}2.05 \\
-8.47 \\
-5.59 \\
0.49 \\
-9.06 \\
-6.80 \\
1.53\end{array}$ & $\begin{array}{r}0.32 \\
-9.02 \\
-2.04 \\
1.92 \\
-8.81 \\
-5.06 \\
2.43\end{array}$ \\
\hline $\begin{array}{l}\text { V } \\
\text { IV } \\
\text { IV } \\
\text { IV } \\
\text { II } \\
\text { II } \\
\text { III } \\
\text { III }\end{array}$ & $\begin{array}{l}.0309 \\
.0230 \\
.0174 \\
.0174 \\
.0141 \\
.0141 \\
.0234 \\
.0150\end{array}$ & $\begin{array}{l}.0351 \\
.0193 \\
.0211 \\
.0211 \\
.0138 \\
.0138 \\
.0147 \\
.0179\end{array}$ & $\begin{array}{l}-8.91 \\
-7.81 \\
-6.35 \\
-6.35 \\
-5.97 \\
-5.97 \\
-7.52 \\
-5.94\end{array}$ & $\begin{array}{l}-9.69 \\
-7.06 \\
-7.06 \\
-7.06 \\
-5.91 \\
-5.91 \\
-5.82 \\
-6.51\end{array}$ & $\begin{array}{l}.0280 \\
.0204 \\
.0130 \\
.0130 \\
.0163 \\
.0163 \\
.0200 \\
.0134\end{array}$ & $\begin{array}{l}.0303 \\
.0167 \\
.0179 \\
.0179 \\
.0147 \\
.0147 \\
.0127 \\
.0158\end{array}$ & $\begin{array}{r}.29 \\
-.10 \\
-.70 \\
-.70 \\
.04 \\
.04 \\
-.22 \\
-.45\end{array}$ & $\begin{array}{r}. .27 \\
-.32 \\
-.32 \\
-.32 \\
-.17 \\
-.17 \\
-.53 \\
-.35\end{array}$ & $\begin{array}{r}7.21 \\
1.49 \\
-3.29 \\
-3.29 \\
-3.20 \\
-3.20 \\
-0.99 \\
-3.01\end{array}$ & $\begin{array}{r}10.43 \\
0.07 \\
.07 \\
.07 \\
-3.75 \\
-3.75 \\
-3.64 \\
-1.83\end{array}$ \\
\hline
\end{tabular}

See eq 53

ntene (type I) not included.

- See eq 6 and table 12 .

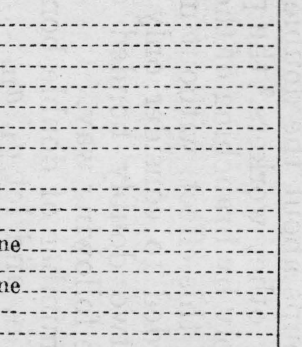

है 
TABLE 10.- Reproducibility of the selected "best" values of molal volume, molal refraction, and boiling point for 58 monoolefins by means of 1 constant (for each property)

\begin{tabular}{|c|c|c|c|}
\hline & $\Delta V^{20}$ & $\Delta R_{D^{20 \mathrm{a}}}$ & $\triangle B P_{760}$ \\
\hline A verage value.... & $\begin{array}{l}m l / m o l e \\
-6.75\end{array}$ & $\begin{array}{l}\mathrm{ml} / \mathrm{mole} \\
-0.36\end{array}$ & ${ }^{\circ} \mathrm{C}$ \\
\hline $\begin{array}{l}\text { Maximum deviation } \\
\text { Standard deviation (of a single value) }\end{array}$ & $\begin{array}{r}4.77 \\
\pm 1.66\end{array}$ & $\begin{array}{r}0.81 \\
\pm 0.29\end{array}$ & $\begin{array}{r}16.50 \\
\pm 4.85\end{array}$ \\
\hline
\end{tabular}

- See eq 53.

classes are shown in table 11. These are the least squares values of the corresponding constants. There is also given the standard deviation (of a single value) for each property, for each type, and also for the entire group. The latter figure represents the error when the 58 olefins are correlated with these 5 constants and should be compared with the standard deviation in table 10 for 1 constant. The improvement is greatest for $\Delta B P_{760}$ and least for $\Delta R_{D}^{20}$.

TABLE 11.-Reproducibility of the selected "best" values of molal volume, molal refraction, a and boiling point for 58 monoolefins by means of 5 constants, 1 for each type (for each property)

\begin{tabular}{|c|c|c|c|c|c|c|c|}
\hline \multirow{2}{*}{ Type } & \multirow{2}{*}{$\begin{array}{l}\text { Number } \\
\text { of com- } \\
\text { pounds }\end{array}$} & \multicolumn{2}{|c|}{$\Delta V^{20}$} & \multicolumn{2}{|c|}{$\Delta R_{D^{20 \mathrm{~s}}}$} & \multicolumn{2}{|c|}{$\triangle B P_{700}$} \\
\hline & & $\begin{array}{c}\text { A verage } \\
\text { value }\end{array}$ & $\begin{array}{c}\text { Devia- } \\
\text { tion }\end{array}$ & $\begin{array}{c}\text { A verage } \\
\text { value }\end{array}$ & $\begin{array}{c}\text { Devia- } \\
\text { tion }\end{array}$ & $\begin{array}{c}\text { Average } \\
\text { value }\end{array}$ & $\begin{array}{c}\text { Devia- } \\
\text { tion }\end{array}$ \\
\hline $\begin{array}{l}\text { I- } \\
\text { II } \\
\text { III. } \\
\text { IV. } \\
\text { V... }\end{array}$ & $\begin{array}{r}13 \\
20 \\
10 \\
13 \\
2\end{array}$ & $\begin{array}{r}\mathrm{ml} / \text { mole } \\
-4.83 \\
-6.72 \\
-7.13 \\
-7.93 \\
-10.22\end{array}$ & $\begin{array}{r}m l / \text { mole } \\
\pm 1.02 \\
\pm 0.75 \\
\pm 1.08 \\
\pm 1.42 \\
\pm 1.26\end{array}$ & $\begin{array}{r}m i / m o l e \\
-0.54 \\
-.33 \\
-.51 \\
-.17 \\
+.19\end{array}$ & $\begin{array}{r}m l / m o l e \\
\pm 0.14 \\
\pm .22 \\
\pm .26 \\
\pm .25 \\
\pm .32\end{array}$ & $\begin{array}{c}{ }^{\circ} \mathrm{C} \\
-6.91 \\
-2.04 \\
-0.13 \\
+2.87 \\
+11.24\end{array}$ & $\begin{array}{l}{ }^{\circ} C \\
\pm 1.65 \\
\pm 1.84 \\
\pm 2.64 \\
\pm 3.76 \\
\pm 4.01\end{array}$ \\
\hline I to $\mathrm{V}$ & 58 & & \pm 1.07 & & \pm 0.22 & & \pm 2.59 \\
\hline
\end{tabular}

see eq 53.

The five constants introduced above take account only of the number and location of alkyl groups about the double bond. However, as has been pointed out by other workers, ${ }^{9}$ the properties of a monoolefin are affected considerably by branching of the alkyl groups. In order to take some account of this effect, without introducing too many complications, it was decided to consider only branching on carbon atoms adjacent to the two doubly bonded carbon atoms. The constants were defined in the following way.

Let $z_{\mathrm{I} i}, z_{\mathrm{II} i}, \ldots, z_{\mathrm{V} i}$ be the number of double bonds of types I, $\mathrm{II}, \ldots, \mathrm{V}$ in the $i$ th monoolefin, and let $a_{\mathrm{I}}, a_{\mathrm{II}}, \ldots, a_{\mathrm{v}}$ be the contributions of each type of bond to $\Delta G$. Obviously, for each monoolefin one of the numbers $z_{\mathrm{I}}, z_{\mathrm{II}}, \ldots, z_{\mathrm{V}}$ is unity and the remaining four are zero. In spite of this apparently trivial reduction, the formalism is convenient in the least squares solution. In addition, let $z_{1 i}, z_{2 i}, z_{3 i}$, and $z_{4 i}$ be the number of primary, secondary, tertiary, and quarternary carbon atoms, respectively, adjacent to the

- See reference [8] and the references given there. 
two doubly bonded carbon atoms in the $i$ th monoolefin, and let $a_{1}$, $a_{2}, a_{3}$, and $a_{4}$ be their contributions to $\Delta G$. Then $\Delta G_{i}$, for the $i$ th monoolefin may be written

$$
\begin{gathered}
\Delta G_{i}=z_{\mathrm{Ii}} a_{\mathrm{I}}+z_{\mathrm{II} i} a_{\mathrm{III}}+z_{\mathrm{III} i} a_{\mathrm{III}}+z_{\mathrm{IV} i} a_{\mathrm{IV}}+z_{\mathrm{V} i} a_{\mathrm{V}} \\
+z_{1 i} a_{1}+z_{2 i} a_{2}+z_{3 i} a_{3}+z_{4 i} a_{4} .
\end{gathered}
$$

It is easily seen that one redundant $z$ has been introduced, which may be eliminated from the relation

$$
z_{1 i}+z_{2 i}+z_{3 i}+z_{4 i}=z_{\mathrm{I} i}+2 z_{\mathrm{II} i}+2 z_{\mathrm{III} i}+3 z_{\mathrm{IV} i}+4 z_{\mathrm{V} i} \text {. }
$$

If $z_{1 i}$ is eliminated, $\Delta G_{i}$ becomes

$$
\Delta G_{i}=z_{\mathrm{Ii}} b_{\mathrm{I}}+z_{\mathrm{II} i} b_{\mathrm{II}}+z_{\mathrm{III} i} b_{\mathrm{III}}+z_{\mathrm{IV} i} b_{\mathrm{IV}}+z_{\mathrm{V} i} b_{\mathrm{V}}+z_{2 i} b_{2}+z_{3 i} b_{3}+z_{4 i} b_{4}
$$

where the new constants, the $b$ 's, are related to the $a$ 's by the equations

$$
\begin{aligned}
& b_{\mathrm{I}}=a_{\mathrm{I}}+a_{1} \\
& b_{\mathrm{II}}=a_{\mathrm{II}}+2 a_{1} \\
& b_{\mathrm{III}}=a_{\mathrm{III}}+2 a_{1} \\
& b_{\mathrm{IV}}=a_{\mathrm{IV}}+3 a_{1} \\
& b_{\mathrm{V}}=a_{\mathrm{V}}+4 a_{1} \\
& b_{2}=a_{2}-a_{1} \\
& b_{3}=a_{3}-a_{1} \\
& b_{4}=a_{4}-a_{1}
\end{aligned}
$$

The following reductions in the coefficients of the normal equations (see eq 9) facilitate the solution for the least squares values of the constants ( $\sum_{i}$ indicates summation over the entire group of monoolefins, $\Sigma_{i}$ over those of type I, etc.

$$
\begin{gathered}
\sum_{i} z_{\mathrm{I} i}^{2}=\sum_{i} z_{\mathrm{I} i}^{2}=\sum_{i} \mathrm{I}(1), \text { etc. } \\
\sum_{i} z_{\mathrm{I} i} z_{\mathrm{II} i}=0, \text { etc. }
\end{gathered}
$$

That is, the sums in which only one roman subscript occurs are equal to the number of olefins of the corresponding type, whereas the sums in which the roman subscripts are different all vanish. As a result the normal equations are easily reduced to three simultaneous linear equations for $b_{2}, b_{3}$, and $b_{4}$, after which $b_{\mathrm{I}}, b_{\mathrm{n}}, \ldots, b_{\mathrm{V}}$ are obtained from separate equations.

The values of the $b$ 's corresponding to $\Delta V^{20}, \Delta R_{D}{ }^{20}$, and $\triangle B P_{700}$, obtained by fitting eq 56 by least squares (see also section II) to the data on the 58 monoolefins, are given in table 12 . 
TABLE 12.-Values of the constants to be used in calculating the difference in molal volume, $\Delta V^{20}$, in molal refraction, $\Delta R_{D^{20}}$, and in normal boiling point, $\Delta B P_{760}$, between a given monoolefin and the corresponding paraffin hydrocarbon having the same carbon'skeleton ${ }^{\sharp}($ see eq 56 )

\begin{tabular}{|c|c|c|c|c|}
\hline$=$ & Constant & For $\Delta V^{20}$ & For $\Delta R_{D^{20}}$ & For $\triangle B P_{760}$ \\
\hline 8 & & $\begin{array}{r}m l / m o l e \\
-6.57 \\
-8.66 \\
-9.26 \\
-9.45 \\
-10.74 \\
+1.05 \\
+2.39 \\
+2.75\end{array}$ & $\begin{array}{c}m l / \text { mole } \\
-0.72 \\
-.51 \\
-.69 \\
-.32 \\
+.11 \\
+.16 \\
.00 \\
+.34\end{array}$ & $\begin{array}{r}{ }^{\circ} \mathrm{C} \\
-3.46 \\
+1.60 \\
+3.52 \\
+5.63 \\
+12.03 \\
-1.60 \\
-5.56 \\
-5.35\end{array}$ \\
\hline
\end{tabular}

- See eq 53.

The manner in which eq 56 and the constants of table 12 reproduce, by difference from the corresponding parent paraffin hydrocarbon, the data on 58 monoolefins, is shown in table 9 , in which the calculated and experimental values are compared, and is summarized in tables 13 and 14. Table 13 shows, for $V^{20}, R_{D}{ }^{20}$, and $B P_{760}$, the standard deviation (of a single value), for each type of olefin, as well as for the entire group. Table 14 shows, for the entire group of 58 monoolefins, the average deviation, the maximum deviation, and the standard deviation (of a single value) for each of the 5 properties: $V^{20}, d^{20}$, $R_{D}{ }^{20}, n_{D}{ }^{20}$, and $B P_{760}$.

TABLE 13.-Reproducibility of the selected "best" values of molal volume, molal refraction, and boiling point for 58 monoolefins by means of 8 constants (see eq 56)

\begin{tabular}{|c|c|c|c|c|}
\hline \multirow{2}{*}{ Type } & \multirow{2}{*}{$\begin{array}{l}\text { Number of } \\
\text { compounds }\end{array}$} & \multicolumn{3}{|c|}{ Standard deviation (of a single value) } \\
\hline & & $V^{20}$ & $R_{D^{20 \mathrm{~s}}}$ & $B P_{760}$ \\
\hline $\begin{array}{l}\text { I } \\
\text { IIII } \\
\text { IV } \\
\text { V }\end{array}$ & $\begin{array}{r}13 \\
20 \\
10 \\
13 \\
2\end{array}$ & $\begin{array}{r}m l / \text { mole } \\
\pm 0.54 \\
\pm 0.53 \\
\pm 1.19 \\
\pm 0.84 \\
\pm .78\end{array}$ & $\begin{array}{r}m l / m o l e \\
\pm 0.16 \\
\pm .18 \\
\pm .28 \\
\pm .59 \\
\pm .02\end{array}$ & $\begin{array}{l}{ }^{\circ} \mathrm{C} \\
\pm 0.83 \\
\pm 1.35 \\
\pm 1.74 \\
\pm 2.50 \\
\pm 3.23\end{array}$ \\
\hline I to $V_{-.}$ & 58 & \pm 0.77 & 0.21 & \pm 1.74 \\
\hline
\end{tabular}

- See eq 53.

TABLE 14.-Reproducibility of the selected "best" values of molal volume, density, molal refraction, " refractive index, and boiling point for 58 monoolefins by means of 8 constants (see eq 56)

\begin{tabular}{|c|c|c|c|c|c|}
\hline Deviation & $V^{20}$ & $d^{20}$ & $R_{D^{20} a}$ & $n_{D}{ }^{20}$ & $B P_{760}$ \\
\hline $\begin{array}{l}\text { Average } \\
\text { Maximum } \\
\text { Standard (of a single value) }\end{array}$ & $\begin{array}{r}m l / m o l e \\
\pm 0.56 \\
1.89 \\
\pm 0.71\end{array}$ & $\begin{array}{l}g / m l \\
\pm 0.0031 \\
.0097 \\
\pm .0038\end{array}$ & $\begin{array}{r}m l / \text { mole } \\
\quad \pm 0.15 \\
\quad \pm 0.64 \\
\quad \pm 0.20\end{array}$ & $\begin{array}{r} \pm 0.0020 \\
.0073 \\
\pm .0025\end{array}$ & $\begin{array}{l}{ }^{\circ} \mathrm{C} \\
\quad \pm 1.33 \\
\quad 4.91 \\
\pm 1.74\end{array}$ \\
\hline
\end{tabular}

- See eq 53.

Values of $\Delta V^{20}, \Delta R_{D}{ }^{20}$, and $\Delta B P_{760}$, obtained from eq 56 and the constants in table 12 , were also calculated for the 66 octenes (cisand trans-isomers are not distinguished by the present method of calculation) and these values are given in table 15. 
TABLE 15.-Calculated values of the difference, between each of 66 octenes and the corresponding octane having the same carbon skeleton, of the density, $d$, at $20^{\circ} \mathrm{C}$, the refractive index, $n_{D}$, at $20^{\circ} \mathrm{C}$, and the boiling point, $\mathrm{BP}$, at $760 \mathrm{~mm} \mathrm{Hg}$ (see eq 56 and table 12 )

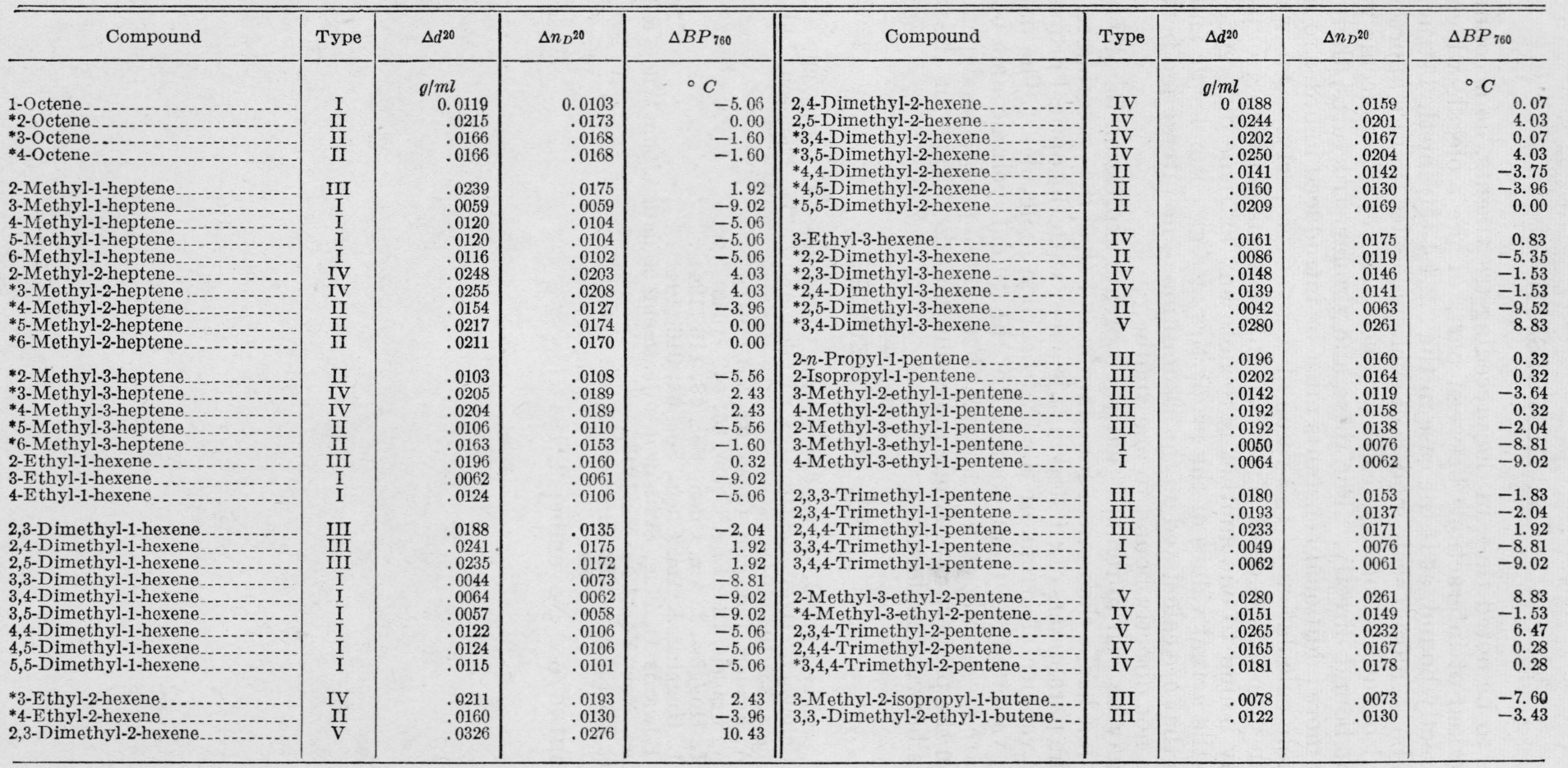

*Cis and trans forms. 


\section{DISCUSSION}

It is to be noted that, in the preceding treatments, no account has been taken of interactions between parts of the molecule which are not directly bound, as is the case in the 2,2,4,4-tetramethyl structure. It can be seen from scale models of such molecules that an appreciable amount of interaction may exist between parts of the molecule which are not bound directly. For these and similar structures, therefore, one or more additional constants must be introduced in order to make a reliable calculation of the value of a given property. One way of deducing the existence of significant interactions between groups not directly bound to one another is to note any extreme differences between the actual values of the properties of a given molecule and the values that are calculated on the assumption of no interaction between groups not directly bound to one another.

It may be well to remark that the Lorentz expression for the molal refraction has a theoretical foundation and that it is possible to connect the parameters evaluated in this paper with the optical properties of the valence electrons of the hydrocarbon molecules. The parameters evaluated in connection with the molal volume and boiling point are essentially empirical since these phase properties depend not only on the properties of single molecules but also largely on the interactions between molecules.

\section{REFERENCES}

[1] G. Calingaert and J. W. Hladky, J. Am. Chem. Soc. 58, 153 (1936).

[2] G. Calingaert, H. A. Beatty, R. C. Kuder, and G. W. Thomson, Ind. Eng. Chem. 33, 103 (1941).

[3] A. W. Francis, Ind. Eng. Chem. 33, 554 (1941).

[4] A. W. Francis, Ind. Eng. Chem. 35, 442 (1943).

[5] M. L. Huggins, J. Am. Chem. Soc. 63, 116 (1941).

[6] M. L. Huggins, J. Am. Chem. Soc. 63, 916 (1941).

[7] W. Edwards Deming, Statistical adjustment of data (John Wiley \& Sons, Inc., New York, N. Y., 1943).

[8] C. E. Boord, Petroleum Refiner, 21, 371 (1942).

Washington, November 2, 1944. 